\title{
Impact of Regional Factors on Cohort Fertility: New Estimations at the District Level in Germany*
}

\author{
Martin Bujard, Melanie Scheller
}

\begin{abstract}
Incorporating the regional context into fertility research has a long standing tradition. However, in Germany, fertility data at the district level only exist for period total fertility rates (TFR), but not for cohort total fertility rates (CTFR). Based on the 2011 census and birth statistics, we estimate the CTFR at the district level and analyse factors influencing their variation.

First, we estimate the CTFR for the 1969-72 cohorts in all 402 German districts. The estimated CTFR differ strongly across German districts ranging between 1.05 and 2.01. Further, the estimated CTFR differ substantially from the known TFR values. This is mainly due to biases in the tempo component of the TFR, which are crucial in East German districts, university cities and in urban-rural comparisons. Therefore, the estimated CTFR allow for a better assessment of fertility differences across districts.

Second, we analyse the differences in the newly estimated CTFR employing regression models. Composition effects such as a low proportion of highly educated women, a high share of Catholics or immigrants are significantly associated with higher CTFR in West German districts. However, regional opportunities are also important: A low population density, the availability of relatively spacious dwellings, a surplus of males, a small service sector and low unemployment rates are associated with higher fertility. Overall the analyses show regional factors are highly relevant for fertility.
\end{abstract}

Keywords: Cohort fertility · Population geography · Regional context · Urbanisation · Germany · Census

This article contains supplementary material in the form of an online Appendix: DOI 10.12765/ CPoS-2017-08en,

URL: http://www.comparativepopulationstudies.de/index.php/CPoS/article/view/270/241. 


\section{Introduction}

Fertility research can basically be divided into two groups of studies: those that examine individual data and those that compare countries at the macro level. Both approaches often exclude regional factors, which, due to considerable regional differences in reproductive behaviour (Basten et al. 2011) leads to selection bias or whole-nation bias (Rokkan 1970). Since variance of fertility at the district level is often very high such as in Germany and local opportunity structures also differ with regard to economic, political and cultural factors (BBSR 2015), it is essential to enhance fertility research by including district-specific factors.

The reasons for regionally divergent fertility rates can be diverse: regional variance can be caused by composition effects (Hank 2002; Hank/Huinink 2015), by different regional opportunity structures (overview: Basten et al. 2011), or by historically evolved cultural patterns (K/üsener/Goldstein 2014). The regional factor most often cited in current research is undoubtedly the negative association between fertility and urbanisation level (Kulu et al. 2007; Kulu/Boyle 2009; Trovato/Grindstaff 1980), which, however, may incorporate different mechanisms (Sharlin 1986); in particular factors such as housing (Fiori et al. 2014; Kulu 2013) and selective internal migration (Courgeau 1989; Kulu/Milewski 2007). Regions with comparatively comprehensive family policies (Baizan 2009; Rindfuss et al. 2007), a high level of religiosity (Sobotka/Adigüze/ 2002) and low unemployment rates (Kravdal 2002) are associated with higher fertility levels. However, the findings in Europe are in part contradictory due to country-specific differences on the one hand, and the specific research designs and data sets on the other. Many regional analyses only cover some of the potential influencing factors by testing a few regional variables in multilevel event-history models. This research approach may allow for causal interpretation, but often at the cost of a selection bias that masks the diversity of potential regional variables and their interactions.

Until now, data for quantifying fertility differences at the regional level - and in particular the district level - in Germany as well as for analysing their influencing factors was limited because of missing data on cohort fertility at the district level. Although there is detailed data on period total fertility rates (TFR, also known as PTFR) at the district level (Grünheid 2015; BBSR 2015), the TFR is less suited as dependent variable since it is biased by the timing component (Bongaarts/Feeney 1998; Schoen 2004). Cohort total fertility rates (CTFR) are superior when regional differences are analysed. The CTFR (or the average number of children per woman per age cohort) at the district level and the analysis of its influencing factors are a substantial research gap in demographic and geographical analysis. Although the 2011 census did not survey the number of biological children, it does have the potential for closing this research gap by using demographic estimation models.

This article has two objectives:

- to calculate the average number of children per woman and an estimated CTFR for all 402 German districts based on the 2011 census and 
- to generate a broad overview of regional explanatory factors and to analyse their interactions in the context of socio-structural factors.

For the calculation of the CTFR, a large number of cases is needed since sufficient cases for cohort-specific numbers of children need to be available for all districts, including the smaller ones. Even the 2012 microcensus, a sample of 688,931 persons, was too small for reliable estimates at the district level. The 2011 census allows us to enter new territory: It has sufficient observations with 7.9 million persons, or approximately 10 percent of Germany's population, reporting. Since the census does not directly collect data on the number of children ever born, we use the information on the number of children in the household (family level) to calculate an estimated value for the CTFR for all 402 German districts. We can generate the most exact possible estimated value for the CTFR at the district level by identifying the female cohorts that have largely come to the end of their reproductive phase and for which the children still largely live in the parents' household. We calculate the cohort-specific underestimation compared to the official population statistics based on multipliers differentiated by East and West Germany. ${ }^{1}$ The CTFR values at the district level are provided in geographical maps and in tables in the appendix as well as in an Excel-file in an additional online appendix.

The influencing factors for fertility differences in German districts are operationalised by linear regression analysis at the macro level, whereby the 402 districts are the cases and the previously calculated CTFR is the dependent variable. To investigate composition effects, socio-demographic variables such as education, religion, migration background and living arrangements are aggregated with the census microdata based on our own calculations. District-specific data on the labour market, economic structure, women's employment, prosperity, urbanisation, family policies, housing and gender proportions are taken from the INKAR ${ }^{2}$ database (BBSR 2015) and provide indicators of regional opportunity structures. This enables to consider both regional and socio-demographic influencing factors of fertility.

\section{Research context}

\subsection{Fertility data for the districts in Germany}

The statistical offices of the federal states (Länder) calculate the TFR at the district level by adding up age-specific fertility rates (ASFR) for every age in a specific year. These values are available for individual years such as 2013 (Grünheid 2015; not including Thuringia). INKAR (BBSR 2015) provides data series on the TFR based on data on births and deaths from the Federal Statistical Office and the Statistical Of-

1 East Germany covers the six eastern states (Länder) and West Berlin.

2 INKAR is a German acronym for "Indicators, Maps and Graphics on Spatial and Urban Monitoring". 
fices of the German Länder as well as on the Eurostat Regio database. The INKAR calculates the TFR on the basis of five-year age intervals such as 15-19, 20-24 etc. (We use these data for a comparison with the computed CTFR in section 4.1.)

So far, there is no cohort fertility data at the district level in Germany. Official birth statistics calculate the CTFR by adding up ASFR for every specific year of time and cohort, whereby the age is calculated as the difference between year of birth and year of report (Statistisches Bundesamt 2014). However, they only provide CTFR for Germany as a whole or separately for East and West. Sociological surveys and the 2012 microcensus, which collect the number of biological children, do not have sufficient sample sizes for calculating district-specific cohort fertility. The 2012 microcensus covers 688,931 cases, with an average of 4,569 cases in the 1969-72 female cohorts, which corresponds to 13 cases per district. The census includes 7.9 million cases, an average of 48,484 cases for each female cohort from 1969-72, which corresponds to an average of 121 cases per district. If we add up, for example, four cohorts, the average number of cases is 482 per district.

The CTFR at the district level is a valuable indicator of regional fertility differences and the regional opportunities that influence them, because it measures the fertility over a woman's reproductive lifetime. By contrast, the TFR is a different concept which measures the timing respective the "speed of travel" of fertility. At the district level the interpretability of the TFR is limited due to the extent of young women's internal migration - university students, in particular - and the varying degrees of delayed childbearing. The timing effect is problematic (Schoen 2004), since the postponement of childbearing and the average childbearing age differ considerably from region to region. University towns such as Heidelberg, Münster and Würzburg with a high number of academics have a mean age at childbearing (MAC) of 32.5-33.3 years. By comparison, the 2013 MAC in rural regions like the Mecklenburg Lake District and Vorpommern-Rügen was 27.0-27.4 years (Grünheid 2015).

\subsection{State of research on regional fertility differences}

Two fundamentally different explanations are cited for regional differences in fertility: they may either result from composition effects or from regional opportunity structures (Basten et al. 2011; Boyle et al. 2007; Firoi et al. 2014; Hank 2002; Hank/Huinink 2015; Kulu/Boyle 2009; Kulu et al. 2007; Trovato/Grindstaff 1980). Although most authors assume that both explanations complement each other, some consider the composition effects to be more relevant (Hank 2002; ${ }^{3}$ Hank/Huinink 2015), while others emphasise regional context factors (Kulu et al. 2007; Kulu/Boyle 2009). This differentiation is important for the significance of regional analysis, because both the whole-nation bias in macroanalysis (Rokkan 1970) and selection bias caused by masking regional factors in individual analysis are stronger the greater the effect of regional context factors.

3 Nonetheless, Hank points out the necessity of further research, e.g. through the use of largescale individual datasets (Hank 2002: 296). 
Composition effects mainly lead to regional fertility differences when people with socio-structural characteristics that exhibit specific fertility behaviours are over or under represented in certain regions. In countries in which higher education is associated with lower fertility, fertility is clearly lower in regions where particularly large numbers of highly educated people and fewer women with lower educational levels live (Hank/Huinink 2015). The situation is similar for socio-economic status (Kulu 2013). Composition effects can also be based on groups of immigrants or ethnic minorities who are overrepresented in specific regions and show different fertility behaviours. Fertility rates among immigrants of different countries of origin are quite heterogeneous. In Germany and the UK, where the majority of immigrants come from countries with considerably higher fertility rates - such as Turkey or Pakistan - the immigrants' effect is positive (Hank/Huinink 2015; Kulu/Washbrook 2014). Other studies show no influence by shares of international immigrants, particularly compared with the distinct effects of internal migration (Michielin 2002). Individual variables with regard to living arrangements (Hank 2003) or employment also prove significant in many analyses (Hank/Huinink 2015). Interpreting them as composition effects, however, is difficult since these factors can also be the result of fertility events or at least of varying degrees in the desire to have children.

Regional context factors are based on local opportunity structures (in detail: Basten et al. 2011), which differ with regard to urbanisation, housing, culture, family policies and employment market.

One central factor is urbanisation (Courgeau 1989; Kulu/Boyle 2009; Kulu et al. 2007; Kulu 2013; Trovato/Grindstaff 1980), which already had negative associations with fertility in historical demography and the first demographic transition (Andorka 1978; Sharlin 1986; Wolf 1912). In an international comparison of 145 countries, population density exhibits a negative correlation with fertility (Lutz et al. 2006), although this only applies to Europe to a certain extent. Interpreting the impact of urbanisation on fertility decisions is complicated, however, because the underlying mechanisms are quite diverse. Sharlin (1986: 236) calls urban-rural differences a "code phrase for an array of social, economic, and cultural differences and changes". The mechanisms behind the urbanisation effect can be differentiated as local opportunity structures, selective internal migration, cultural factors (including the timing of transitional processes) and composition effects:

- Certain local opportunity structures typically differ between urban and rural regions: In cities, housing is scarcer and more expensive, and the labour market is characterised by a higher level of specialisation and is more knowledge-based; both factors are associated with low fertility. In rural districts, by contrast, access to nature can contribute to local recreation and a healthier lifestyle, and less road traffic to a more child-friendly living environment. It is, however, worthwhile to analyse the factors individually for two reasons. The first is to isolate the actual influencing factors behind urbanisation. Secondly, differentiating the local opportunity structures in cities is advisable since there are also urban spaces with family-friendly living environments. A number of studies show that fertility is higher in suburbs than in city centres (Boyle et al. 2007; Kulu/Boyle 2009; Kulu/Washbrook 2014). 
- Selective internal migration (Courgeau 1989; Huinink/Wagner 1989; Kulu/ Milewski 2007; Michielin 2002) intensifies urban-rural differences in fertility. Frequently, couples move from cities to the countryside shortly before or after having their first child, while childless couples tend to move to cities. For France, Courgeau (1989) shows that internal migration from the city to the countryside is accompanied by higher fertility (and vice versa). He does not only prove this for the transition to first birth, but also for transitions to higher parities. Some argue that women adapt their behaviours to the new environment or choose an environment according to their childbearing preferences, whereby the housing market plays an important role. Since some suburbs belong to a city and others to bordering rural districts, delimitation can cause problems.

- Cultural differences between urban and rural districts are caused by various socio-cultural milieus. City milieus have urban lifestyles, which are characterised by many options outside family life. Urban lifestyles and local opportunity structures interact with one another. The influence of these milieus and social learning is greater for starting a family than the transition to other parities (Fiori et al. 2014). Urban-rural differences can also depict the avantgarde and latecomers to historic transformation processes such as the first demographic transition (Coale/Watkins 1986).

Selective internal migration occurs, however, not only in the urban-rural context, but generally between different districts with different regional contexts. Kulu and Milewski (2007) presented an elaborate system in which they examine four hypotheses for fertility behaviours of migrants: According to the socialisation hypothesis, the fertility rates of adults remain constant after migration because their preferences were formed before migration. By contrast, the adaptation hypothesis postulates that the regional context has a greater influence and that fertility adapts to the dominant patterns in the new environment. The selection hypothesis presumes that migration is caused by specific fertility preferences (for the UK: Kulu/ Washbrook 2014). The disruption hypothesis suggests that fertility is lower immediately after migration; this hypothesis is less plausible for internal migration than for international migration (with the exception of family reunification). Unlike the findings by Courgeau (1989) for France, by Huinink and Wagner (1989) for Germany and by Michielin (2002) for Italy, more recent analyses show no effect of selective migration for the transition to the second and third child for the UK (Fiori et al. 2014) and for the first three parities in Finland (Kulu 2013).

In multiple studies, housing is shown to be a significant regional context factor (Fiori et al. 2014; Kulu/Vikat 2007; Kulu/Boyle 2009; Kulu 2013). For Finland, Kulu shows that living in detached and row houses during the transition to the first child has a distinct effect that even explains the more frequent transition in rural areas (Kulu 2013: 904). A higher probability of transitioning to a third child could also be shown for Finland among people living in single-family houses (Kulu/Vikat 2007). For the UK, Fiori et al. (2014) ascertain a positive effect of dwellings with more than five rooms only among people transitioning to their second child.

Cultural differences at the regional level that evolved historically and often arose prior to the present political system (cf. Klüsener/Goldstein 2014) can affect regional fertility differences. The significance of culture in relation to socio-economic differ- 
ences is emphasised by the authors of the European Fertility Project (Coale/Watkins 1986). While a certain degree of modernisation was a prerequisite for the pretransitional decline in the fertility rate, the point in time when it set in was primarily influenced by the regional cultural setting (Knodel/van de Walle 1986). This is not applicable to the denominational imprint of large Prussian cities; additionally, contagious effects between neighbouring geographical regions play a role (Goldstein/ Klüsener 2014). Recent studies also point out the influence of regionally different social milieus on fertility (Fulda 2015). However, "culture" in terms of fertility-related attitudes is, to a certain extent, influenced nationally through language and mass media (Lesthaeghe 1995).

Religious denominations and varying levels of religiosity, measured for instance by weekly church attendance, are a keystone for cultural analysis. A number of studies show that a high rate of frequent church attendance contributes to explaining regional fertility differences (Kemper 1991; Sobotka/Adigüzel 2002). A century ago, higher fertility rates or the low inclination for contraception among Catholics were emphasised (Wolf 1912; cf. Goldstein/Klüsener 2014). However, in more recent international comparisons Catholicism is associated with lower fertility as a result of family-policy deficiencies in Catholic countries (Castles 2003). Analyses of 28 OECD countries show that the share of Protestants is associated positively with the TFR between 1987 and 2006, whereby the childcare and Protestant quotas explain a similar variance in multivariate regressions (Bujard 2011). In many countries there is only one dominant denomination. Germany is an interesting case since it has districts that are primarily Catholic (e.g. in southern Bavaria) and others that are primarily Protestant (e.g. in Schleswig-Holstein). The proportions also sometimes differ considerably within individual $L$ änder. Besides denomination, religiosity is decisive, whereby East Germany - not only due to the former GDR regime - is particularly secular (Klüsener/Goldstein 2014). Studies that examine regional fertility differences in Germany in the context of churches and religiosity are rare. Using a path model, Kemper (1991) shows a direct positive influence of church attendance rates and an indirect negative influence of the share of Protestants for 31 West German administrative districts.

More recent studies on the influence of family policies on fertility on the national level show a positive effect (Bujard 2011; Luci-Greulich/Thévenon 2013). Although several family policies are national in scope, especially child-care policies have a within variation in some countries. The findings on the influence of family policies on regional differences in fertility, in particular with regard to childcare, are mixed. Rindfuss et al. (2007) ascertain a positive effect of day-care centres on the transition to the first child for Norway. Findings for Germany (Bauernschuster et al. 2013; Hank et al. 2004) are varied, whereby a more recent publication by Bauernschuster et al. takes the expansion of childcare centres in West Germany into consideration and is able to show that this led to a small increase in fertility. For Spain, Baizan (2009) proves a positive effect of formal childcare, which is intensified by a higher female employment rate in the transition to higher parities.

Regional labour markets sometimes differ considerably between municipalities with regard to the unemployment rate, the economic structure and women's 
employment. The influence of unemployment is closely tied to a region's prosperity. The increasing vocational and economic uncertainty in young adulthood (Mills/ Blossfeld 2005) is particularly distinct in the service industry and alongside high unemployment rates. For both factors, negative effects on fertility have been identified for Norway (Kravdal 2002), whereby aggregated regional effects are more decisive than individual effects. Hank and Huinink (2015) prove mixed findings for Germany: a positive effect of unemployment on the number of children and a negative effect on the intention of having a child in the next two years.

\section{Data, methodology and research design}

\subsection{Data}

This study is based on the microdata from the 2011 census household survey (Bechtold 2016). Within this household survey, approximately 10 percent of the German population, namely about 7.9 million people, were asked for additional sociodemographic information that is not contained in the registry data (Statistisches Bundesamt 2010). The household sample is based on a regionally stratified random sample of addresses drawn from the population registers. All people at a selected address were obliged to provide information. People at sensitive special facilities such as psychiatric or penal institutions, military bases abroad, police departments and the Foreign Service, as well as their families, are not included in the household survey, since providing information could result in social disadvantages for these population groups.

The household and familial relationships of all individuals residing at an address were not requested directly, but were instead produced later as part of a household generation procedure (Statistisches Bundesamt 2015; Kreuzmair/Reisch 2013). To do this, traditional household and familial relationships were generated using direct cross-references from the population registers such as marriages, registered same-sex partnerships or descendants' relationships. Information on descendants is usually available until they reach the age of 18 . Cross-references contained in the register beyond that age were also included in the household generation. In order to associate other forms of living arrangements such as cohabitation, other information from registers was used, for example arrival information or moving addresses.

The microdata of the census are structured within a relational data model in which all partial datasets of the census are filed as individual tables and can be linked to one another using identifiers. Within this study, the individual data from the household survey is used as well as the familial relationships estimated during household generation after national typing. Since family information is not available in smaller municipalities, these people were excluded from the analysis.

First all women in the household sample were selected. Next, the generated relationships regarding family type and family size were used to estimate the num- 
ber of children of each woman. ${ }^{4}$ The sample results were extrapolated to the census population using an extrapolation factor to enable comparisons with other data sources. It must be noted that the place of residence of the woman at the time of the census date was used, rather than her residence at the time of childbearing.

At the time of the census survey there were 412 districts in Germany. As a result of the territorial reforms in Mecklenburg-West Pomerania in 2011, 18 districts were merged into eight districts. All data for these districts were converted based on Kühntopf (2015) so that all the results that are cited here are valid for 402 districts, in line with the district count as per 1 January 2015.

\subsection{Calculating the multiplier and estimating the CTFR}

We use census data on the number of children per woman living in the household present in the Census to estimate the CTFR. The number of biological children and therefore also the final number of children are not included in the census. The number of children in the household in the census particularly underestimates the final number of children for two reasons: Firstly, children who have already left home are not included, whereby the number of children recorded in particular among women over the age of 38 increasingly underestimates the CTFR. Secondly, the final number of children is underestimated among female cohorts younger than age 45 because they are still of childbearing age.

We identify the cohorts containing the least biases between the number of children in the household and the CTFR. Figure 1 compares census values and microcensus values for the number of children in the household to the final number of children based on official birth statistics $(1960-70)^{5}$ and linear trend extrapolation $(1971-75) .{ }^{6}$ The comparison shows that the deviation is smallest -6.6 percent to 7.8 percent - for 38- to 42-year-old women, namely the 1969-72 cohorts. The difference between the children in the household and the final number of children grows with increasing distance from these cohorts. This underestimation is certainly a disadvantage, but since the census does not provide information on births, there is no alternative to this method. We estimate an average CTFR for all four cohorts 1969-72 in order to have enough cases for computing it for each district. The underestimation is within limits due to the selection of the 1969-72 cohorts.

4 Note that for this study, the reproductive behaviour of women in general is relevant and is not modelled at the family level. Therefore, women in same-sex partnerships are recorded as two cases. Another limiting factor is that due to the methodology of household generation, identifying mothers in multigenerational families may lead to an under-reporting of children. The family concept of the 2011 census refers to direct (first-degree) relationships between ascendants and descendants.

5 For the 1970 cohort, the data from the official birth statistics account for the period cohort fertility rate (PCFR) up to and including age 42 . Birth rates after this age are very low; their effect adds up to $<=0.01$.

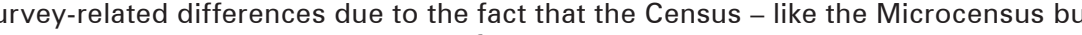
unlike the birth statistics - includes children of immigrant women that were born abroad (cf. Pötzsch 2010). 
Fig. 1: Comparison of the average number of children in a household (census and microcensus) and the CTFR (official birth statistics and linear extrapolation) for the female cohorts 1960-75 in Germany

Average number of children

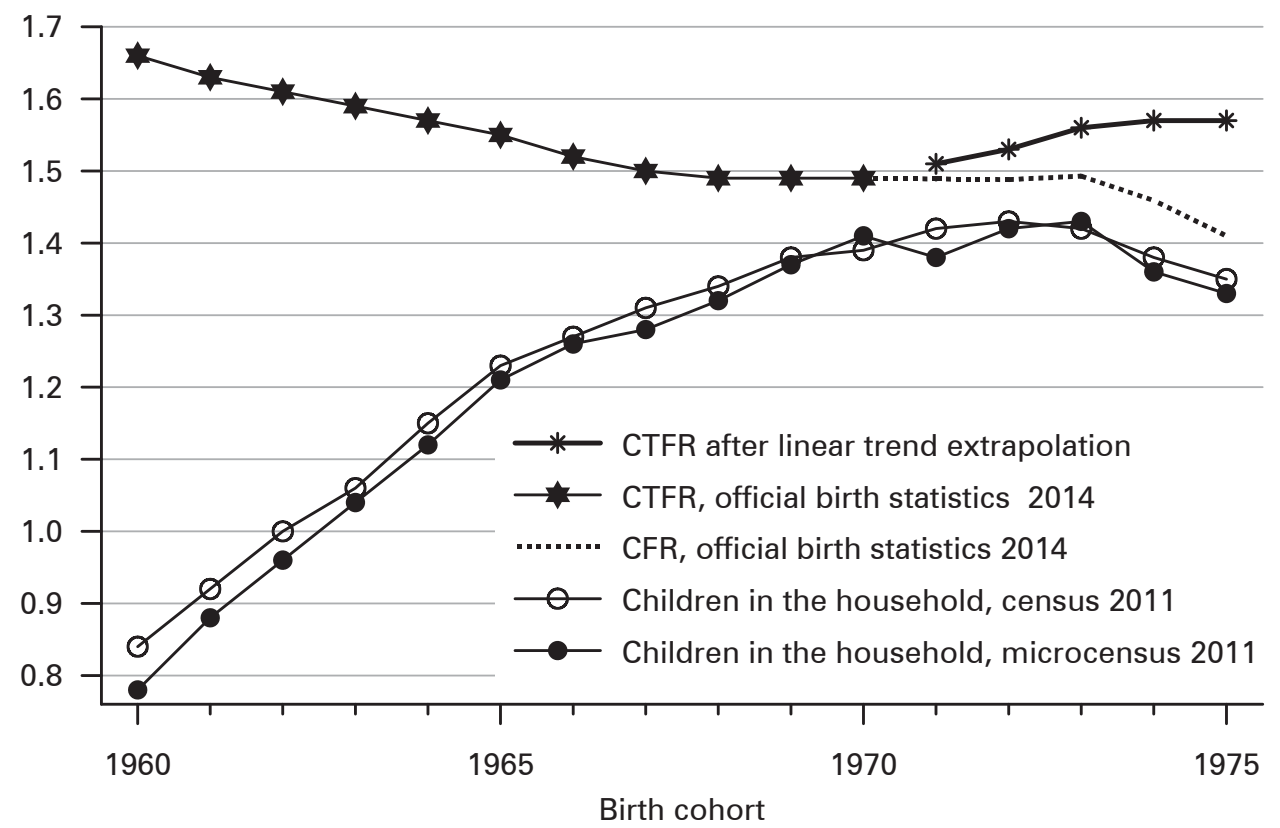

Source: Own calculations based on 2011 census and 2011 microcensus; also Statistisches Bundesamt (2014); Goldstein/Kreyenfeld (2013).

The CTFR of the 1969-72 cohorts is underestimated by the census by 7.17 percent using the number of children in the household. It is plausible that the underestimation is relatively evenly distributed among the districts and that differences are particularly associated with a younger childbearing age and the associated earlier move out of the parental home. This especially applies to East Germany, where the age at first childbirth is considerably lower (Statistisches Bundesamt 2014), meaning that more children of East German mothers in the 1969-72 cohorts had already left their parental home in 2011. Accordingly, the underestimation is only 5.86 percent in West Germany, while it is much higher in East Germany, at 12.20 percent (Table 1). A further differentiation between large cities and other regions would further improve the estimated value; however, this is only possible for the federal city-states due to missing data. Besides, the complexity of the procedure would be disproportionate to the gains in precision. Since the number of children in the households underestimates the CTFR to a much greater degree in East Germany, a differentiated multiplier for West and East Germany is applied. These multipliers and the district-specific values on the average number of children in the household 
Tab. 1: Comparison of the average number of children in the household according to the census and CTFR

\begin{tabular}{lllllllllll}
\hline \multirow{2}{*}{$\begin{array}{l}\text { Birth } \\
\text { cohort }\end{array}$} & \multicolumn{3}{c}{ CTFR (birth statistics) } & \multicolumn{3}{c}{ 2011 census } & \multicolumn{3}{c}{ Difference (CTFR - census) } \\
& East & West & Total & East & West & Total & East & West & Total & Total in \% \\
\hline 1960 & 1.80 & 1.60 & 1.66 & 0.56 & 0.91 & 0.84 & 1.23 & 0.69 & 0.82 & 97.3 \\
1961 & 1.76 & 1.58 & 1.63 & 0.63 & 0.99 & 0.92 & 1.13 & 0.59 & 0.71 & 77.6 \\
1962 & 1.72 & 1.56 & 1.61 & 0.69 & 1.08 & 1.00 & 1.03 & 0.48 & 0.61 & 61.1 \\
1963 & 1.68 & 1.54 & 1.59 & 0.75 & 1.14 & 1.06 & 0.93 & 0.40 & 0.52 & 49.3 \\
1964 & 1.64 & 1.53 & 1.57 & 0.86 & 1.22 & 1.15 & 0.78 & 0.30 & 0.41 & 35.9 \\
1965 & 1.60 & 1.52 & 1.55 & 0.94 & 1.30 & 1.23 & 0.67 & 0.22 & 0.33 & 26.5 \\
1966 & 1.56 & 1.50 & 1.52 & 1.04 & 1.32 & 1.27 & 0.52 & 0.17 & 0.25 & 19.8 \\
1967 & 1.55 & 1.47 & 1.50 & 1.13 & 1.35 & 1.31 & 0.42 & 0.12 & 0.19 & 14.2 \\
1968 & 1.51 & 1.47 & 1.49 & 1.20 & 1.37 & 1.34 & 0.31 & 0.10 & 0.15 & 11.1 \\
\hline 1969 & 1.49 & 1.48 & 1.49 & 1.28 & 1.40 & 1.38 & 0.21 & 0.07 & 0.11 & 7.8 \\
1970 & 1.46 & 1.49 & 1.49 & 1.29 & 1.42 & 1.39 & 0.17 & 0.07 & 0.10 & 7.2 \\
1971 & 1.50 & 1.51 & 1.51 & 1.37 & 1.43 & 1.42 & 0.13 & 0.09 & 0.09 & 6.6 \\
1972 & 1.51 & 1.53 & 1.53 & 1.38 & 1.44 & 1.43 & 0.14 & 0.10 & 0.10 & 7.1 \\
\hline 1973 & 1.53 & 1.57 & 1.56 & 1.38 & 1.43 & 1.42 & 0.15 & 0.14 & 0.14 & 9.8 \\
1974 & 1.54 & 1.57 & 1.57 & 1.35 & 1.39 & 1.38 & 0.19 & 0.19 & 0.18 & 13.3 \\
1975 & 1.54 & 1.58 & 1.57 & 1.33 & 1.35 & 1.35 & 0.21 & 0.23 & 0.22 & 16.6 \\
\hline
\end{tabular}

Notes: Differences are caused by rounding. The cohorts shaded grey are included in this analysis.

Source: Own calculations based on the 2011 census (extrapolated values) and official birth statistics (1960-70: Statistisches Bundesamt (2014); 1971-75: Goldstein/ Kreyenfeld (2013).

per woman in the census are used to estimate the CTFR of the 1969-72 female cohorts for all 402 districts.

\subsection{Sensitivity analysis: Comparison of the census findings with the microcensus}

In the following, we check the calculated census values for the average number of children of women in the household (family level) by comparing them with microcensus values from the same year ${ }^{7}$ (see Table 2). A comparison with the 2012 microcensus would have an advantage because questions on biological births were included here; however, the selected cohorts are still of childbearing age. Therefore, a comparison of census and microcensus results from the same year and with

7 Both surveys took place in 2011. The reference day for the census was 9 May 2011, while the microcensus survey - due to the sub-annual survey methodology - took place at various times. We assume that for the cohorts selected here the monthly differences caused by this lead to an insignificant bias. 
Tab. 2: Average number of children of women in the household: Comparison of the census and microcensus

\begin{tabular}{lcccccccccc}
\hline & \multicolumn{3}{c}{ 2011 microcensus } & \multicolumn{3}{c}{ 2011 census } & \multicolumn{3}{c}{ Difference (microcensus - census) } \\
& East & West & Total & East & West & Total & East & West & Total & Total in \% \\
\hline 1960 & 0.48 & 0.86 & 0.78 & 0.56 & 0.91 & 0.84 & -0.08 & -0.05 & -0.06 & -7.1 \\
1961 & 0.56 & 0.96 & 0.88 & 0.63 & 0.99 & 0.92 & -0.07 & -0.03 & -0.04 & -4.3 \\
1962 & 0.62 & 1.05 & 0.96 & 0.69 & 1.08 & 1.00 & -0.07 & -0.03 & -0.04 & -4.0 \\
1963 & 0.70 & 1.12 & 1.04 & 0.75 & 1.14 & 1.06 & -0.05 & -0.02 & -0.02 & -1.9 \\
1964 & 0.81 & 1.20 & 1.12 & 0.86 & 1.22 & 1.15 & -0.05 & -0.02 & -0.03 & -2.6 \\
1965 & 0.90 & 1.30 & 1.21 & 0.94 & 1.30 & 1.23 & -0.04 & 0.00 & -0.02 & -1.6 \\
1966 & 1.00 & 1.32 & 1.26 & 1.04 & 1.32 & 1.27 & -0.04 & 0.00 & -0.01 & -0.8 \\
1967 & 1.04 & 1.34 & 1.28 & 1.13 & 1.35 & 1.31 & -0.09 & -0.01 & -0.03 & -2.3 \\
1968 & 1.14 & 1.35 & 1.32 & 1.20 & 1.37 & 1.34 & -0.06 & -0.02 & -0.02 & -1.5 \\
1969 & 1.25 & 1.40 & 1.37 & 1.28 & 1.40 & 1.38 & -0.03 & -0.00 & -0.01 & -0.7 \\
1970 & 1.28 & 1.44 & 1.41 & 1.29 & 1.42 & 1.39 & -0.01 & 0.02 & 0.02 & 1.4 \\
1971 & 1.28 & 1.40 & 1.38 & 1.37 & 1.43 & 1.42 & -0.09 & -0.03 & -0.04 & -2.8 \\
1972 & 1.38 & 1.43 & 1.42 & 1.38 & 1.44 & 1.43 & -0.00 & -0.01 & -0.01 & -0.7 \\
1973 & 1.40 & 1.42 & 1.43 & 1.38 & 1.43 & 1.42 & -0.02 & -0.01 & 0.01 & 0.7 \\
1974 & 1.32 & 1.35 & 1.36 & 1.35 & 1.39 & 1.38 & -0.03 & -0.04 & -0.02 & -1.4 \\
1975 & 1.31 & 1.35 & 1.33 & 1.33 & 1.35 & 1.35 & -0.02 & 0.00 & -0.02 & -1.5 \\
\hline
\end{tabular}

Note: The difference in percent is the quotient from the total difference and the total census value.

Source: 2011 census, 2011 microcensus, own calculation.

comparable variables is more informative for checking the plausibility of the census analysis.

The differences in the average number of children of women for the 1960-75 cohorts and for East and West Germany are only minimal, ranging between 0.00 and 0.09. This precision confirms selection and filters described in Section 3.1. This is only possible because the case numbers in the microcensus and the census are extremely high and the surveys are less biased by non-response problems due to the obligation to respond.

\subsection{Research design of the multivariate analysis}

The multivariate and spatial analysis serves the purpose of generating a broad overview of district-specific factors of the CTFR, their interaction and the spatial clusters. In the linear regression analysis the 402 districts function as cases, whereby separate analyses are conducted for Germany as a whole as well as for West and East Germany. This differentiation has two reasons: (1) the literature refers to great demographic, cultural and structural differences between the two German regions (e.g. Goldstein/Kreyenfeld 2011; Schneider et al. 2012), and (2) our own preliminary analysis indicates considerable east-west differences. These differences cannot be well captured through the use of an east-west dummy since it interacts differently 
with multiple independent variables. The district level used here has certain limitations since, as in all macro-analysis at the district level, the Modifiable Areal Unit Problem (MAUP) (Openshaw 1984) occurs, which can lead to interpretative problems in multivariate analysis (Fotheringham/Wong 1991).

The dependent variable is the district-specific CTFR calculated in this study for women of the 1969-72 cohorts. For these cohorts, the census 2011 covers 193,934 cases of women; all those cases were included in the calculation of the 402 districtspecific CTFR values.

The independent variables are based on district-specific aggregations of the microdata from the 2011 census household sample (composition variables) as well as on the INKAR database (districts' opportunities; BBSR 2015). The census aggregations are calculated for the same cohorts (1969-72) as the dependent variable and using the district convertor for the territorial reform in Mecklenburg- West Pomerania. The following proportions are used as independent composition variables: migration background, low educational level (ISCED 1-2), high educational level (ISCED 5A, 6), Catholics, Protestants, married women, cohabitating women as well as the sum of married and cohabitating women.

The average values from 1995-2011 (if available) ${ }^{8}$ were used to measure districts' opportunities, since the influence of these factors is crucial in the phase of reproductive decisions over the life course. For women who were about 40 years old 2011 , this phase comprises the past ten or more years. The following variables are used (Metadata see: BBSR 2015): Employment rate in the tertiary sector, unemployment rate (as a share of the total civil labour force), employment rate in research and development (R\&D), percentage of women working part-time, employment rate of women, labour force participation rate of women, gross domestic product per capita, gross wage and salary, percentage of child poverty, childcare rate for children aged $0-2$, care rate of preschool children aged 3-5, all-day care rate of preschoolage children, ${ }^{9}$ teaching staff in day-care facilities in relation to the number of children, percentage of dwellings with five and more rooms, floor area per person in square meters, area closer to nature per resident and the gender proportion of 20 to 39 -year-olds (relation of women/men). The natural logarithm (base e) of the population density (inhabitant per square $\mathrm{km}$ ) is used to capture the urbanisation effect.

8 Values from 1995-2011 are available for most of the INKAR (BBSR 2015) variables. The data series does not go as far back for the following variables: unemployment rate from 1998, gross salary from 2000, R\&D employment rate from 2003, childcare rates from 2007, employment rate in the tertiary sector and women's employment rate from 2008 . This is a disadvantage, but based on the development of the other variables we can assume that the relation of these variables between the districts was relatively similar for the entire time period.

9 This indicator measures the share of three- to five-year-old children in day-care centres supervised for seven and more hours per day. 


\section{$4 \quad$ Results}

\subsection{CTFR at the district level}

The results for the average CTFR of the 1969-72 cohorts for all 402 districts are displayed in Figure 2. Each value and a numbered key to each district name are shown in Table A-1 in the appendix and in an Excel table in the online appendix. The spectrum ranges from 1.05 in Passau to 2.01 in Cloppenburg (see Fig. 3). The CTFR is below 1.3 in 28 districts, in particular in big cities like Cologne, Hamburg, Stuttgart or Munich. It is above 1.7 in 44 districts. Many of these districts with a relatively high cohort fertility are located in the Allgäu, in the region of the Odenwald, in southern Franconia, in eastern Saxony and in the region between Münster and Emsland.

Regarding the question of district-specific influence on the lifetime fertility of women the estimated CTFR is more informative and easier to interpret than the TFR. Due to missing data of CTFR on the district level the TFR is sometimes used to answer such questions but it is often misinterpreted. There are fundamental differences between both concepts which can be illustrated by an age-time Lexis diagram (Luy 2010). The TFR does not only reveal the quantum, but also a timing effect (Bongaarts/Feeney 1998). Further, womens' internal migration affects both measures differently in many districts. We illustrate this in the following by comparing the CTFR with available TFR data at the district level.

The data basis for the TFR values is estimated by the BBSR (2015). For comparison, we use the TFR of those years in which the mother cohorts 1969-72 reached the mean age at childbearing (MAC). In the year 1999 the MAC was 30.1 years, or roughly the age of the women born in 1969 (Statistisches Bundesamt 2012). By 2003 the MAC rose to 30.67 years, which corresponds with the 1972 cohort. Accordingly, the average TFR values of the years 1999-2003 are used for the comparison with the CTFR values of the 1969-72 cohorts for the districts. Using this 5-year average also has the advantage that it smoothens TFR fluctuations at the district level. Comparing the CTFR and TFR is fundamentally problematic. Here, the aim is to show how, and why, the CTFR diverges considerably from the previously known TFR values.

The correlation between the two fertility indicators at the district level has a Pearson correlation coefficient of 0.56 . The high deviation from 1 demonstrates that it makes a big difference whether a cohort measurement (CTFR) or a period measurement (TFR) is considered. The CTFR is on average 0.12 higher when comparing CTFR (1969-72) and TFR (1999-2003) values; therefore, the TFR underestimates the actual births per woman. This is even more problematic for fertility data at the district level for two reasons: (1) when the postponement of childbearing takes place at a different speed (and therefore the bias diverges due to the timing effect) and (2) due to internal migration between districts. Both have considerable effects on the TFR of the districts in Germany. The question of how many children women in specific districts have cannot be answered appropriately using the TFR at the district level. However, the advantage of the TFR is that it delivers very current data.

The data on the final number of children, by contrast, enable us to answer the question of how many children women of a cohort have. Temporarily childless 
Fig. 2: CTFR at the district level: estimated values for the 1969-72 cohorts

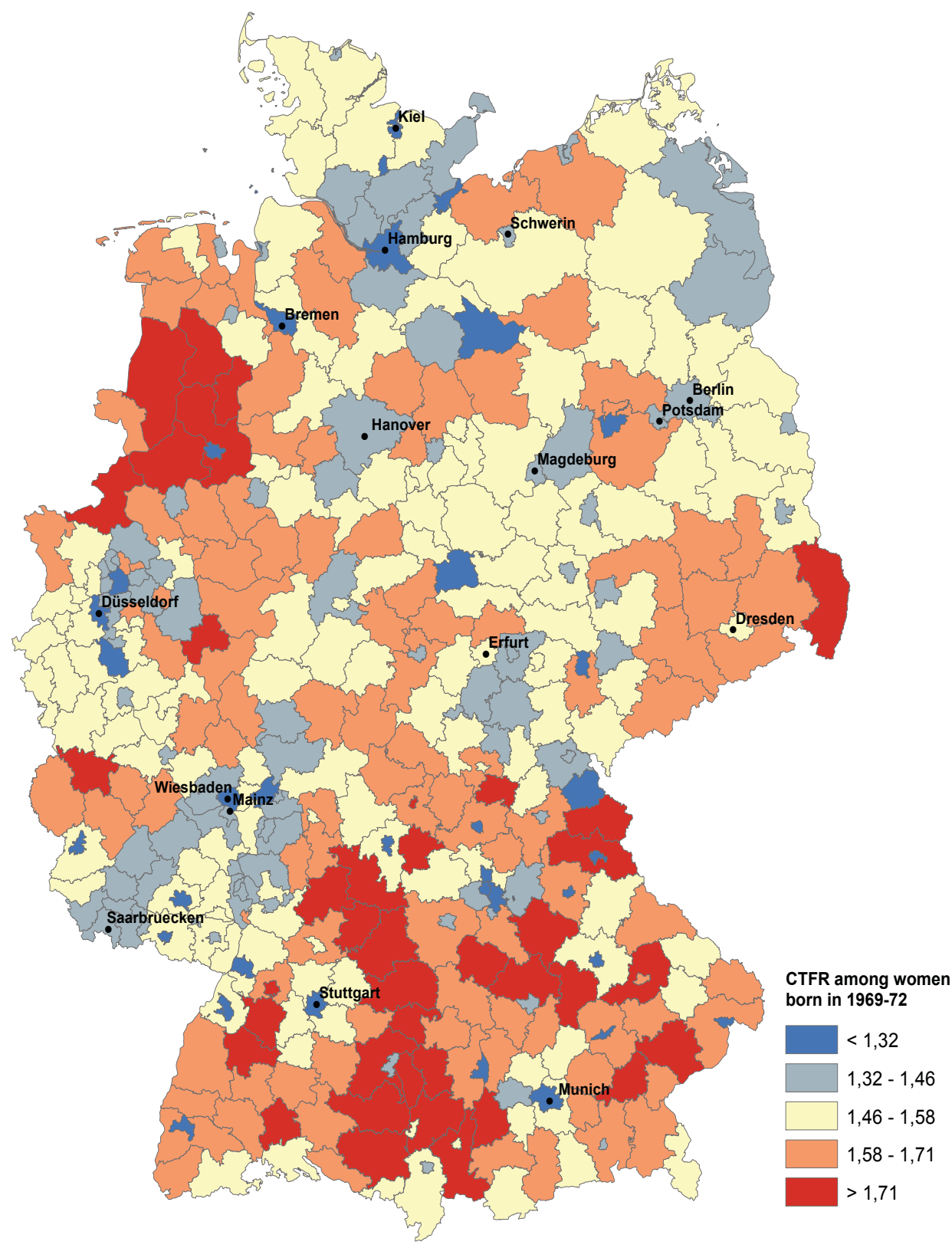

Note: A map with a numbered key and a list with the names of the districts and each CTFR value are provided in the appendix. Further, an excel-sheet with the districts CTFR can be downloaded at:

http://www.comparativepopulationstudies.de/index.php/CPoS/article/view/270/241

Source: Own calculations based on the 2011 census. Map: (C) GeoBasis-DE/BKG (2015). 
Fig. 3: Estimated CTFR at the district level: Top 10 and Bottom 10

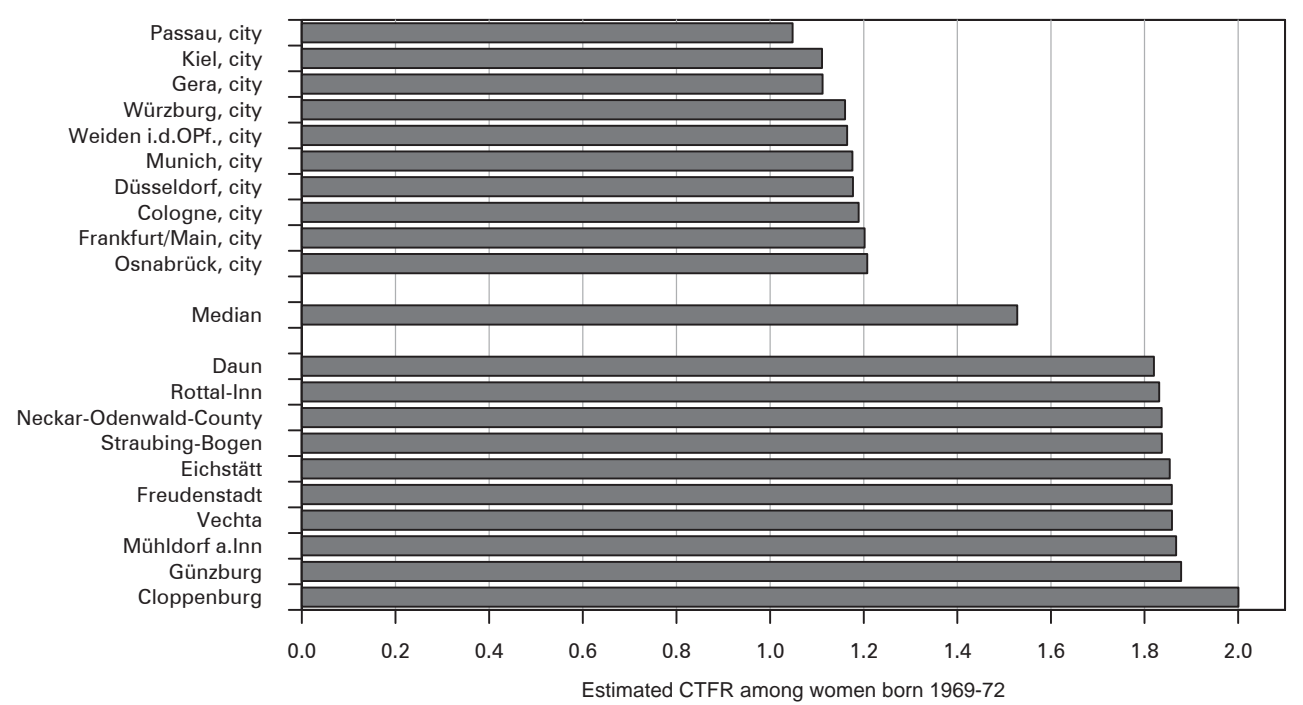

Source: Own calculations based on the 2011 census.

women who move to another city for studies have a negative effect on the TFR of that city because they are included in the denominator, which may lead to a considerable underestimation of the fertility of women in university towns. These phenomena lead to a deviation between the CTFR and TFR at the district level of +0.50 in the Brandenburg district of Elbe-Elster and -0.30 in Lüchow-Dannenberg (Lower Saxony), a range of more than 0.80 . The district-specific variation in the TFR bias compared to the CTFR is considerable, whereby three phenomena are of central importance:

1. The timing component of the TFR is particularly distinct in East Germany because the delay of MAC was exceedingly high following reunification. Accordingly, the CTFR in nearly every East German district is at least 0.2 higher than the TFR, and more than 0.3 higher in 37.7 percent of districts. Of the 77 East German districts, only Gera has a higher TFR.

2. Urban-rural migrations following childbirth are visible in several districts, whereby families with young children tend to move from the city to neighbouring rural districts. This phenomenon is especially visible in Cologne, Düsseldorf, Essen and Frankfurt/Main and particularly distinct in Bavaria, where Munich, Ingolstadt, Amberg, Weiden, Nuremberg, Fürth and Erlangen have a lower CTFR than their TFR.

3. The CTFR is significantly higher than the TFR in several university cities such as Münster (0.33), Tübingen (0.23) and Heidelberg (0.48), which is largely caused by female students who are only temporarily living in these cities and have a low fertility during this time. 


\subsection{Macro-analysis of district-specific factors of the CTFR}

Based on the newly generated data on cohort fertility at the district level, we are able to analyse district-specific factors at the macro level. Table 3 shows the correlations between the CTFR and some socio-structural, economic, political and geographical factors, the figures are differentiated for Germany as a whole and West and East Germany.

There are distinct differences regarding the socio-structural factors in West and East Germany. For example, the negative correlation between the CTFR and the unemployment rate as well as the CTFR and the share of cohabitating couples is only significant in West Germany. The characteristics of the religion variable is notable: while a high percentage of Catholics is only significantly associated with higher cohort fertility in West Germany, the negative sign associated with the Protestant share for the whole of Germany conceals a significant positive correlation for East Germany. The childcare rates are only significantly negative in West Germany. The correlation between the CTFR and all-day childcare is negative, which demands explanation. Since both variables correlate with unemployment $(r=0.71$ and 0.67 for Germany), it might conceal a spurious correlation. In addition, due to the relevant time period they are only informative to a limited extent for the fertility of the selected female cohorts (see 3.4).

Since urbanisation is cited in the literature as a central factor in regional fertility differences (see 2.2), the negative correlation between population density and number of children per woman is illustrated in Figure 4. The population density is logarithmised because of its skewed distribution. The correlation between the two variables is significantly negative; the Pearson's $r$ correlation coefficient is 0.54 .

In the following, we show the results of the linear regression analysis for Germany, whereby the 402 districts are the cases (see Table 4). ${ }^{10}$ In Model 1 we show the composition variables only, in Model 2 and 3 we include the variables of districts' opportunities influenced by social structure, and in Model 4 we include the variables of districts' opportunities. Model 5 is the best-fit model when focussing only on six variables. The negative effect of the employment rate in the tertiary sector, the population density and a gender proportion with few men is robust and highly significant for all models $(p<0.001)$. The share of Catholics and the percentage of dwellings with five rooms and more are also significantly positive, whereby the level of significance varies between the models. For example, the $t$ value for the share of Catholics drops from 7.1 in Model 1 to 2.2 in Model 5. The percentage of female immigrants has a significantly negative effect in Model 1, but when including the variables of the tertiary sector and population density (Models 3-5) the sign reverses - also to a significant level. Since immigrants tend to live in cities, the negative cor-

$\overline{10}$ To avoid multicollinearity, variables whose intercorrelations reach values above 0.7 are not included in a common regression model. Therefore we use the variable of all-day care of 3-to5 -year-olds in place of the care rate for under 3-year-olds as well as the prosperity indicators of the GDP instead of child poverty and salary. 
Tab. 3: $\quad$ Bivariate correlations at the district level between the CTFR and selected composition factors and districts' opportunity factors

\begin{tabular}{|c|c|c|c|c|}
\hline & Factors/Indicators & Germany & West & East \\
\hline \multirow{12}{*}{ 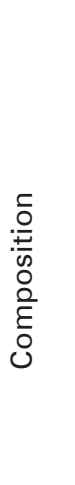 } & Education & & & \\
\hline & Percentage with low education (ISCED 1-2) & -0.05 & $-0.12^{*}$ & -0.19 \\
\hline & Percentage with high education (ISCED $5 \mathrm{~A}, 6$ ) & $-0.49 * * *$ & $-0.52 * * *$ & $-0.33^{* *}$ \\
\hline & Migration & & & \\
\hline & Percentage with migration background & $-0.20 * * *$ & $-0.31 * * *$ & $-0.32 * *$ \\
\hline & Religion & & & \\
\hline & Percentage of Catholics & $0.30 * * *$ & $0.33^{* * *}$ & 0.18 \\
\hline & Percentage of Protestants & -0.03 & -0.10 & $0.38 * * *$ \\
\hline & Civil status & & & \\
\hline & Percentage of married women & $0.64 * * *$ & $0.73^{* * *}$ & $0.66 * * *$ \\
\hline & Percentage of cohabitating women & $-0.23 * * *$ & $-0.31 * * *$ & -0.11 \\
\hline & Percentage of married and cohabitating women & $0.67 * * *$ & $0.68 * * *$ & $0.67 * * *$ \\
\hline \multirow{14}{*}{ 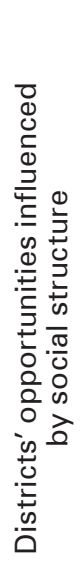 } & Employment market & & & \\
\hline & Employment rate in the tertiary sector & $-0.56^{* * *}$ & $-0.57 * * *$ & $-0.49 * * *$ \\
\hline & Unemployment rate & $-0.28 * * *$ & $-0.42 * * *$ & -0.01 \\
\hline & Percentage of R\&D employees & -0.03 & -0.05 & -0.02 \\
\hline & Women's employment & & & \\
\hline & Percentage of women working part-time & $-0.44 * * *$ & $-0.47 * * *$ & $-0.29 *$ \\
\hline & Employment rate of women & -0.02 & 0.01 & 0.07 \\
\hline & Labour force participation rate of women & $0.21 * * *$ & $0.31 * * *$ & $0.29 *$ \\
\hline & Prosperity & & & \\
\hline & Per capita gross domestic product & $-0.36 * * *$ & $-0.41 * * *$ & $-0.45 * * *$ \\
\hline & Gross wage and salary & $-0.14 * *$ & $-0.23 * * *$ & $-0.33^{* *}$ \\
\hline & Percentage of child poverty & $-0.46^{* * *}$ & $-0.50 * * *$ & $-0.41 * * *$ \\
\hline & Urbanisation & & & \\
\hline & Logarithmised population density & $-0.54 * * *$ & $-0.60 * * *$ & $-0.44 * * *$ \\
\hline \multirow{13}{*}{ 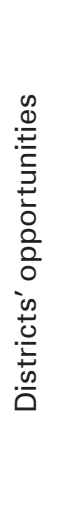 } & Urban/rural district (dummy) & $0.27 * * *$ & $0.30 * * *$ & $0.26 *$ \\
\hline & Family policies & & & \\
\hline & Childcare rate & $-0.20 * * *$ & $-0.38^{* * *}$ & $-0.29 *$ \\
\hline & Care rate of preschool-age children & -0.04 & -0.01 & -0.19 \\
\hline & All-day care rate of preschool-age children & $-0.33^{* * *}$ & $-0.55^{* * *}$ & -0.16 \\
\hline & Teaching staff in day-care facilities & $0.30 * * *$ & $0.47 * * *$ & $0.40 * * *$ \\
\hline & Housing & & & \\
\hline & Percentage of dwellings with 5 and more rooms & $0.59 * * *$ & $0.65^{* * *}$ & $0.48^{* * *}$ \\
\hline & Floor area per person & $0.21 * * *$ & $0.23 * * *$ & -0.02 \\
\hline & Area closer to nature per resident & $0.12^{*}$ & 0.11 & $0.33^{* *}$ \\
\hline & Gender proportion & & & \\
\hline & Gender proportion (age 20-39) & $-0.18 * * *$ & $-0.31 * * *$ & $-0.33^{* *}$ \\
\hline & $\mathrm{N}$ & 402 & 325 & 77 \\
\hline
\end{tabular}

Notes: *** $\mathrm{p}<0.001 ;{ }^{*} \mathrm{p}<0.01 ;{ }^{*} \mathrm{p}<0.05$

Source: Own calculations based on the 2011 census and BBSR (2015). 
Fig. 4: Correlation between the estimated CTFR and the population density in Germany's 402 districts

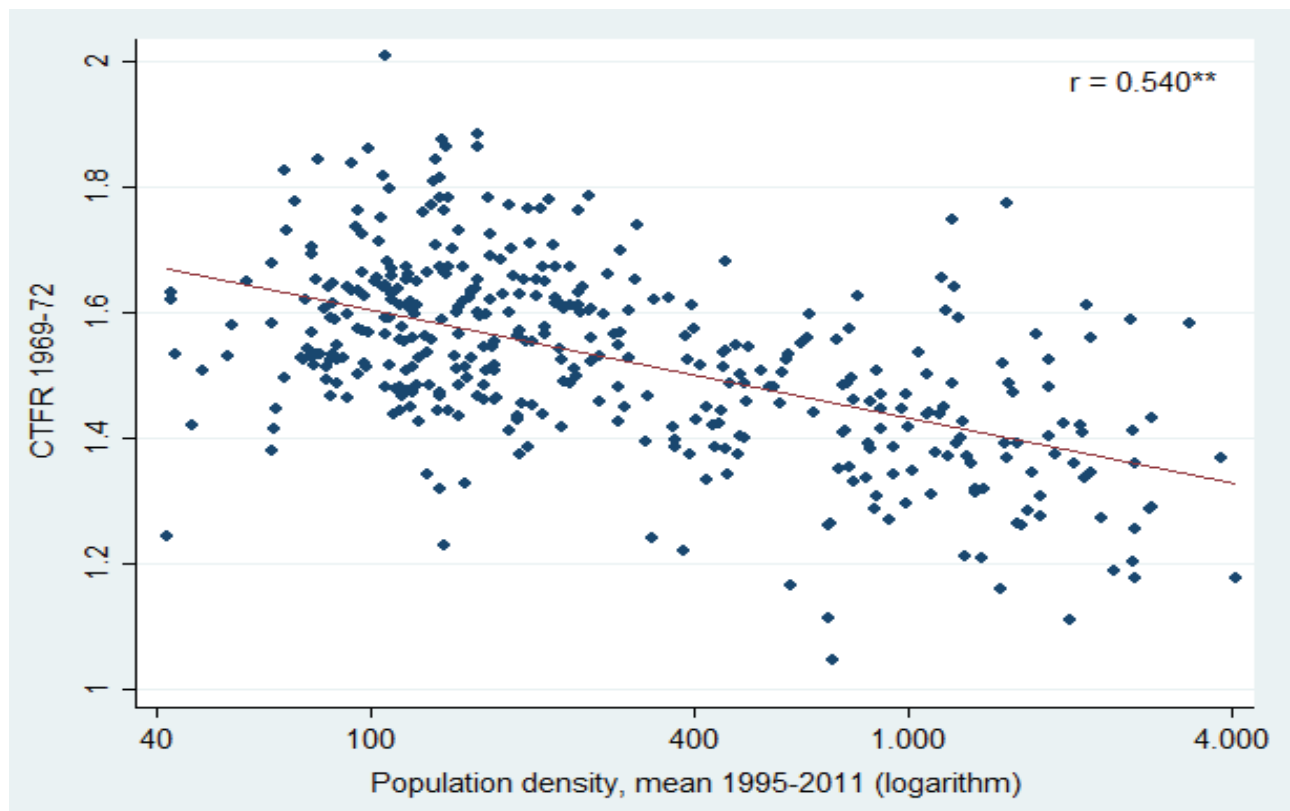

Source: Own calculations based on the 2011 census and BBSR (2015).

relation in Model 1 is an ecological fallacy; it is caused by an overlapping effect of urbanisation. With these six factors, Model 5 attains an adjusted determination coefficient of 0.47. By contrast, the effects of the unemployment rate, part-time work and the percentage of the highly educated lose their significance in those models in which population density and housing are included (Model 4).

In case of the regressions for West Germany, the structure of some models has to deviate somewhat due to problems with multicollinearity. ${ }^{11}$ The models show that composition effects and district-specific opportunities complement each other (Table 5). The best-fit model - W3 - reaches an explanatory power of 0.51 . Consequently, the CTFR is higher in districts in which few highly educated people and many Catholics live (composition effect) as well as in which a low population density, a relatively high share of men, a more traditional economic structure (small tertiary sector) and a low unemployment level (district-specific opportunities) are combined. Besides the effect of gender proportions, all of these variables show robust significant levels in modified models (not shown).

The variables female employment rate and percentage of Catholics explain a similar variance; the latter is only significant when the former is not included (Model

11 Due to excessive intercorrelations, the GDP, the percentage of dwellings with 5 and more rooms and the floor area are not included. Further, the immigrant as well as the population density variable are not included in the same models. 
Tab. 4: OLS regressions on the CTFR at the district level: Germany

\begin{tabular}{|c|c|c|c|c|c|}
\hline & Model 1 & Model 2 & Model 3 & Model 4 & Model 5 \\
\hline $\begin{array}{l}\text { Percentage with high } \\
\text { education }\end{array}$ & $\begin{array}{l}-0.0081^{* * *} \\
(0.0009)\end{array}$ & $\begin{array}{l}-0.0038^{* * *} \\
(0.0011)\end{array}$ & $\begin{array}{l}-0.0015 \\
(0.0011)\end{array}$ & $\begin{array}{c}0.0005 \\
(0.0013)\end{array}$ & \\
\hline $\begin{array}{l}\text { Percentage with } \\
\text { migration background }\end{array}$ & $\begin{array}{l}-0.0018^{* *} \\
(0.0006)\end{array}$ & $\begin{array}{l}-0.0011 \\
(0.0007)\end{array}$ & $\begin{array}{l}0.0024^{* *} \\
(0.0009)\end{array}$ & $\begin{array}{c}0.0022^{*} \\
(0.0009)\end{array}$ & $\begin{array}{l}0.0021^{* *} \\
(0.0008)\end{array}$ \\
\hline $\begin{array}{l}\text { Percentage of } \\
\text { Catholics }\end{array}$ & $\begin{array}{l}0.0019^{* * *} \\
(0.0003)\end{array}$ & $\begin{array}{c}0.00070^{*} \\
(0.00032)\end{array}$ & $\begin{array}{l}0.00085^{* *} \\
(0.00031)\end{array}$ & $\begin{array}{c}0.00073^{*} \\
(0.00031)\end{array}$ & $\begin{array}{c}0.00065^{*} \\
(0.00030)\end{array}$ \\
\hline $\begin{array}{l}\text { Employees in the } \\
\text { tertiary sector }\end{array}$ & & $\begin{array}{l}-0.0037^{* * *} \\
(0.0007)\end{array}$ & $\begin{array}{l}-0.0024^{* * *} \\
(0.0007)\end{array}$ & $\begin{array}{l}-0.0026^{* * *} \\
(0.0007)\end{array}$ & $\begin{array}{l}-0.0026^{* * *} \\
(0.0007)\end{array}$ \\
\hline Unemployment rate & & $\begin{array}{l}-0.0060 * * \\
(0.0020)\end{array}$ & $\begin{array}{l}-0.0060^{*} \\
(0.0024)\end{array}$ & $\begin{array}{l}-0.0005 \\
(0.0030)\end{array}$ & \\
\hline $\begin{array}{l}\text { Percentage of women } \\
\text { working part-time }\end{array}$ & & $\begin{array}{l}-0.0045^{*} \\
(0.0020)\end{array}$ & $\begin{array}{l}-0.0029 \\
(0.0020)\end{array}$ & $\begin{array}{l}-0.0025 \\
(0.0019)\end{array}$ & \\
\hline GDP & & $\begin{array}{l}-0.0012 \\
(0.0011)\end{array}$ & $\begin{array}{l}-0.0017 \\
(0.0011)\end{array}$ & $\begin{array}{l}-0.0017 \\
(0.0010)\end{array}$ & \\
\hline $\begin{array}{l}\text { Logarithmised } \\
\text { population density }\end{array}$ & & & $\begin{array}{l}-0.046^{* * *} \\
(0.010)\end{array}$ & $\begin{array}{l}-0.030^{* *} \\
(0.011)\end{array}$ & $\begin{array}{l}-0.038^{* * *} \\
(0.011)\end{array}$ \\
\hline Gender proportion & & & $\begin{array}{l}-0.61 * * * \\
(0.17)\end{array}$ & $\begin{array}{l}-0.74^{* * *} \\
(0.18)\end{array}$ & $\begin{array}{l}-0.65^{* * *} \\
(0.15)\end{array}$ \\
\hline $\begin{array}{l}\text { All-day care rate of } \\
\text { preschool-age children }\end{array}$ & & & & $\begin{array}{l}-0.00082^{*} \\
(0.00041)\end{array}$ & \\
\hline $\begin{array}{l}\text { Percentage of dwellings } \\
\text { with } 5 \text { and more rooms }\end{array}$ & & & & $\begin{array}{c}0.0025^{*} \\
(0.0010)\end{array}$ & $\begin{array}{l}0.0035^{* * *} \\
(0.0008)\end{array}$ \\
\hline Constants & $\begin{array}{l}1.616^{* * *} \\
(0.016)\end{array}$ & $\begin{array}{l}1.960^{* * *} \\
(0.045)\end{array}$ & $\begin{array}{l}2.595^{* * *} \\
(0.165)\end{array}$ & $\begin{array}{l}2.477^{* * *} \\
(0.194)\end{array}$ & $\begin{array}{l}2.311^{* * *} \\
(0.129)\end{array}$ \\
\hline $\mathrm{R}^{2}$ & $0.326 * * *$ & $0.433^{* * *}$ & $0.483^{* * *}$ & $0.500 * * *$ & $0.479 * * *$ \\
\hline Adj. $R^{2}$ & $0.321 * * *$ & $0.423 * * *$ & $0.471 * * *$ & $0.486^{* * *}$ & $0.472 * * *$ \\
\hline $\mathrm{N}$ & 402 & 402 & 402 & 402 & 402 \\
\hline
\end{tabular}

Notes: Standard errors are reported in parentheses below the coefficients.

*** $\mathrm{p}<0.001$; * $\mathrm{p}<0.01 ;{ }^{*} \mathrm{p}<0.05$

Source: Own calculations based on the 2011 census and BBSR (2015).

W4, W5). Two variables that are significant for Germany as a whole, which were not included due to higher intercorrelations with population density, were additionally tested (models not shown): The immigration effect is significantly positive when the percentage of immigrants is included together with the population density. The positive coefficient of the dwelling size is highly significant when it is used in place of population density. 
Tab. 5: OLS regressions on the CTFR at the district level: West Germany

\begin{tabular}{|c|c|c|c|c|c|}
\hline & Model W1 & Model W2 & Model W3 & Model W4 & Model W5 \\
\hline $\begin{array}{l}\text { Percentage with } \\
\text { high education }\end{array}$ & $\begin{array}{l}-0.0092^{* * *} \\
(0.0010)\end{array}$ & $\begin{array}{l}-0.0097^{* * *} \\
(0.0012)\end{array}$ & $\begin{array}{l}-0.0062^{* * *} \\
(0.0014)\end{array}$ & $\begin{array}{l}-0.0051 * * * \\
(0.0014)\end{array}$ & $\begin{array}{l}-0.0034^{* *} \\
(0.0011)\end{array}$ \\
\hline $\begin{array}{l}\text { Percentage with } \\
\text { migration background }\end{array}$ & $\begin{array}{l}-0.0013 \\
(0.0008)\end{array}$ & $\begin{array}{r}-0.00003 \\
(0.0007)\end{array}$ & & & \\
\hline Percentage of Catholics & $\begin{array}{l}0.0020 * * * \\
(0.0003)\end{array}$ & $\begin{array}{c}0.0004 \\
(0.0024)\end{array}$ & $\begin{array}{c}0.0005 \\
(0.0003)\end{array}$ & $\begin{array}{c}0.0007^{*} \\
(0.0003)\end{array}$ & $\begin{array}{l}0.0011 * * * \\
(0.0003)\end{array}$ \\
\hline $\begin{array}{l}\text { Employees in the } \\
\text { tertiary sector }\end{array}$ & & $\begin{array}{l}-0.0024^{* *} \\
(0.0008)\end{array}$ & $\begin{array}{l}-0.0023^{* *} \\
(0.0008)\end{array}$ & $\begin{array}{l}-0.0022^{* *} \\
(0.0008)\end{array}$ & $\begin{array}{l}-0.0035^{* *} \\
(0.0008)\end{array}$ \\
\hline Unemployment rate & & $\begin{array}{l}-0.026^{* * *} \\
(0.004)\end{array}$ & $\begin{array}{l}-0.020 * * * \\
(0.004)\end{array}$ & $\begin{array}{l}-0.013^{* * *} \\
(0.004)\end{array}$ & \\
\hline $\begin{array}{l}\text { Female employment } \\
\text { rate }\end{array}$ & & $\begin{array}{l}-0.0083^{* * *} \\
(0.0026)\end{array}$ & $\begin{array}{l}-0.0082^{* * *} \\
(0.0025)\end{array}$ & & \\
\hline $\begin{array}{l}\text { Logarithmised } \\
\text { population density }\end{array}$ & & & $\begin{array}{l}0.030 * * * \\
(0.009)\end{array}$ & $\begin{array}{l}0.032^{* * *} \\
(0.009)\end{array}$ & $\begin{array}{l}0.050 * * * \\
(0.007)\end{array}$ \\
\hline Gender proportion & & & $\begin{array}{l}-0.44^{*} \\
(0.20)\end{array}$ & $\begin{array}{l}-0.40^{*} \\
(0.20)\end{array}$ & \\
\hline Constants & $\begin{array}{l}1.617^{* * *} \\
(0.024)\end{array}$ & $\begin{array}{l}2.617^{* * *} \\
(0.219)\end{array}$ & $\begin{array}{l}3.101^{* * *} \\
(0.289)\end{array}$ & $\begin{array}{l}2.388^{* * *} \\
(0.191)\end{array}$ & $\begin{array}{l}2.045^{* * *} \\
(0.054)\end{array}$ \\
\hline $\mathrm{R}^{2}$ & $0.355^{* * *}$ & $0.498^{* * *}$ & $0.523 * * *$ & $0.507^{* * *}$ & $0.484^{* * *}$ \\
\hline Adj. $R^{2}$ & $0.349 * * *$ & $0.489 * * *$ & $0.513^{* * *}$ & $0.498 * * *$ & $0.477^{* * *}$ \\
\hline $\mathrm{N}$ & 325 & 325 & 325 & 325 & 325 \\
\hline
\end{tabular}

Notes: Standard errors are reported in parentheses below the coefficients.

*** $\mathrm{p}<0.001$; * $\mathrm{p}<0.01 ;{ }^{*} \mathrm{p}<0.05$

Source: Own calculations based on the 2011 census and BBSR (2015).

The regressions for East Germany ${ }^{12}$ shown in Table 6 reveal that the percentage of Protestants is significantly and positively associated with the CTFR in all models. In addition, there is a cluster of four factors that are highly intercorrelated and are each highly significant $(p<0.01)$ (Models E2-E5): employees in the tertiary sector, GDP, population density and the percentage of dwellings with 5 and more rooms. In less urban districts the economic structure is more traditional, the GDP lower and more larger dwellings are available. In these districts, there are frequently low shares of young women. Unfortunately, we are unable to interpret which of these factors is decisive due to the intercorrelations and the relatively low number of cases in East Germany.

$\overline{12}$ The results for East Germany must be interpreted carefully due to the low number of cases. 
Tab. 6: OLS regressions on the CTFR at the district level: East Germany

\begin{tabular}{|c|c|c|c|c|c|}
\hline & Model E1 & Model E2 & Model E3 & Model E4 & Model E5 \\
\hline $\begin{array}{l}\text { Percentage with } \\
\text { high education }\end{array}$ & $\begin{array}{l}-0.0026 \\
(0.0020)\end{array}$ & & & & \\
\hline $\begin{array}{l}\text { Percentage with } \\
\text { migration background }\end{array}$ & $\begin{array}{l}-0.0051 \\
(0.0038)\end{array}$ & & & & \\
\hline Percentage of Catholics & $\begin{array}{c}0.0028 \\
(0.0015)\end{array}$ & $\begin{array}{c}0.0026 \\
(0.0014)\end{array}$ & $\begin{array}{c}0.0025 \\
(0.0014)\end{array}$ & $\begin{array}{l}0.0029 * \\
(0.0014)\end{array}$ & $\begin{array}{c}0.0023 \\
(0.0014)\end{array}$ \\
\hline $\begin{array}{l}\text { Percentage of } \\
\text { Protestants }\end{array}$ & $\begin{array}{l}0.0051^{* *} \\
(0.0016)\end{array}$ & $\begin{array}{c}0.0043^{*} \\
(0.0019)\end{array}$ & $\begin{array}{l}0.0052^{* *} \\
(0.0018)\end{array}$ & $\begin{array}{l}0.0054^{* *} \\
(0.0018)\end{array}$ & $\begin{array}{c}0.0046^{*} \\
(0.0019)\end{array}$ \\
\hline Unemployment rate & & $\begin{array}{c}0.0078 \\
(0.0047)\end{array}$ & $\begin{array}{c}0.0041 \\
(0.0050)\end{array}$ & $\begin{array}{c}0.0054 \\
(0.0049)\end{array}$ & $\begin{array}{c}0.0098^{*} \\
(0.0047)\end{array}$ \\
\hline $\begin{array}{l}\text { Employees in the } \\
\text { tertiary sector }\end{array}$ & & $\begin{array}{l}-0.0039^{* *} \\
(0.0012)\end{array}$ & & & \\
\hline GDP & & & $\begin{array}{l}-0.0096^{* *} \\
(0.0032)\end{array}$ & & \\
\hline $\begin{array}{l}\text { Logarithmised } \\
\text { population density }\end{array}$ & & & & $\begin{array}{l}-0.036 * * \\
(0.012)\end{array}$ & \\
\hline $\begin{array}{l}\text { Percentage of dwellings } \\
\text { with } 5 \text { and more rooms }\end{array}$ & & & & & $\begin{array}{l}0.0055^{* *} \\
(0.0017)\end{array}$ \\
\hline Constants & $\begin{array}{l}1.471 * * * \\
(0.041)\end{array}$ & $\begin{array}{l}1.559 * * * \\
(0.139)\end{array}$ & $\begin{array}{l}1.517^{* * *} \\
(0.135)\end{array}$ & $\begin{array}{l}1.504^{* * *} \\
(0.130)\end{array}$ & $\begin{array}{l}1.082^{* * *} \\
(0.101)\end{array}$ \\
\hline $\mathrm{R}^{2}$ & $0.269 * * *$ & $0.318^{* * *}$ & $0.307^{* * *}$ & $0.310 * * *$ & $0.317^{* * *}$ \\
\hline Adj. $\mathrm{R}^{2}$ & $0.229 * * *$ & $0.280^{* * *}$ & $0.268^{* * *}$ & $0.272^{* * *}$ & $0.279 * * *$ \\
\hline $\mathrm{N}$ & 77 & 77 & 77 & 77 & 77 \\
\hline
\end{tabular}

Notes: Standard errors are reported in parentheses below the coefficients.

*** $\mathrm{p}<0.001$; ** $\mathrm{p}<0.01$; ${ }^{*} \mathrm{p}<0.05$

Source: Own calculations based on the 2011 census and BBSR (2015).

\section{Summary and discussion}

The objective of this study was to analyse the influence of district-specific factors of fertility and to generate the data on cohort fertility at the district level in Germany. For the first time, we calculated estimated values for the CTFR for all 402 German districts based on the microdata from the household sample of the 2011 census and official birth statistics. We further used linear regression analysis based on census and INKAR data to analyse fertility differences on the district level. This analysis revealed that district-specific demographic factors such as population density and gender proportions as well as economic variables such as economic structure, dwelling size and unemployment level can contribute to a better understanding of 
district-specific fertility differences. At the same time, the findings show that composition effects with regard to education, religion and immigration are also associated with district-specific fertility differences.

The differences in the estimated district-specific CTFR for the 1969-72 cohorts are substantial, with the spectrum ranging from 2.01 in Cloppenburg to 1.05 in Passau. Women in large cities have the lowest average number of children. The CTFR is above 1.7 in 44 districts, primarily in the Allgäu, in the Odenwald region, in southern Franconia and in the region between Münster and Emsland. The district-specific distribution of the CTFR differs fundamentally from the distribution of the TFR for comparable years (BBSR 2015); the correlation coefficient is only 0.56 . A comparison of both indicators at the district level illustrates that the timing effect intrinsic to the TFR underestimates fertility in particular in East Germany. In addition, the low TFR in university cities is a statistical artefact, since students temporarily raise the denominator for certain age-related, still childless groups. While, for example, the Heidelberg TFR oscillated below 1.0 for many years, the CTFR is 1.36 .

The findings from the multivariate analysis have a wider international relevance since the analysis considers several factors combined which have been discussed in the current literature. For Germany as a whole we have stated that the CTFR is significantly higher in districts

- that have a low number of highly educated women,

- that have a high percentage of Catholics,

- that have a more traditional economic structure (small tertiary sector),

- where unemployment is lower,

- that are more rural,

- with housing markets that offer more large dwellings for families and

- that exhibit a relative surplus of men.

The findings for Germany as a whole are, as expected, similar to those for West Germany, since a majority of the districts (81 percent) lies in West Germany. But they differ between West and East Germany, sometimes profoundly. In East Germany the CTFR is significantly higher in districts

- with large numbers of Protestants and

- that belong to a cluster of variables measuring a lower population density, a more traditional economic structure, a low domestic product and many large dwellings.

Thus, the robust fertility-reducing influence of a high population density in principle confirms the urbanisation hypothesis. This effect remains significant even when other factors are considered although the strength of the effect is reduced when we include the educational variables. Therefore, the considerable urban-rural differences are caused by the two facts that more highly educated women (who tend to postpone childbirth) live in cities and that fewer families with children live there because of less local recreational opportunities and higher extra-familial lei- 
sure activity options. The migration selection effect contributes to this, which states that women with more career ambitions migrate more often to cities and vice versa.

The analysis identified a cluster of variables in the broader context of urbanisation. This is an interesting finding with regard to theory building because it is a starting point for further differentiating the urbanisation theory: in urbanised districts, scarcer housing (Fiori et al. 2014; Kulu/Vikat 2007; Kulu 2013), a modern serviceoriented economic structure, as well as a surplus of women in some cases, and more modern cultural values coincide. These regional opportunity factors increase the explanatory power if we include them in models with population density. The findings substantiate Sharlin's (1986) assumption for the early $21^{\text {st }}$ century that the urbanisation theory is based on geographical, demographic, economic and cultural factors. Education-specific composition effects can be added to them. ${ }^{13}$ This article makes only an initial, tentative approximation. However, additional research could further substantiate the mechanisms in the urbanisation cluster.

The high explanatory power of the religion variables is remarkable - considering it is not only valid for the frequently studied share of Catholics, but also for the East German Protestants. The effect among Catholic dominated districts should also be seen in the context of childcare, which is comparatively less extensive in these districts. This finding contradicts analysis comparing countries (Castles 2003) in which the percentage of Catholics has negative associations with fertility rates. One possible explanation is that the extent of childcare at the district level is highly correlated with denominations (Bujard 2011), while the low childcare supply at the beginning of the century and its expansion since 2005 are phenomena that apply in a similar way to Catholic and Protestant districts in West Germany. This leads to a fundamental question: Does the religious denomination measure a composition effect at all, or is it an indicator of the cultural character of a district that carries a more conservative image of family and envisions large families as something rather desirable (cf. Wolf $1912)$ ? In this case, further analysis is needed.

The gender proportions are also correlated with the CTFR. In the East German districts in particular, where there are 100 men for 80 to 90 women, this is positive for female fertility. Apparently, the favourable situation on the partner market leads to less women remaining without a partner and respectively, the childlessness rate is lower. The extent to which men in such competitive relationship constellations are more prone to have a family in order to keep up the relationship would be an interesting question. An alternative explanation is the migration selection effect.

Including variables measuring the supply of childcare did not lead to consistent effects; however, this certainly does not mean that these factors, which differ considerably between the districts, have no influence. Instead, the effects of the childcare supply and unemployment can only be analysed in a meaningful way when changing rates are quantified over the course of time (e.g. Bauernschuster et

13 Without the migrant effect, according to which disproportionately large numbers of fertile and culturally more traditional immigrant groups live in large cities, the urban-rural differences would be far greater. 
al. 2013). However, a more verified implication for family policy is the high impact of the housing situation on fertility. Because the decline of families with three and more children is decisive for 68 percent of the decline of CTFR between the cohorts 1933 to 1968 in Germany (Bujard/Sulak 2016), it is reasonable that the shortage of dwellings with five and more rooms contribute to a lower fertility level.

The macro-analysis conducted here offers an overview of the factors of district-specific differences for cohort fertility for the first time. They cannot, however, compare the exact variance explanation of the composition effects to that of the regional effects. To do this, multilevel models that adequately use the hierarchical differences of micro- and macro-variables are necessary. In comparison to the international literature, the literature focussing on Germany assigns more dominant roles to composition effects than to regional fertility differences (Hank 2002; Hank) Huinink 2015). This at first contradicts the influence of regional factors seen here. Previous multilevel analyses were carried out with individual datasets (e.g. pairfam, DJI family survey or SOEP) adding district-specific factors. In these analyses, the case numbers are relatively low considering that on average 20 to 50 individual cases are available per district. This leaves us with the central question of what results multilevel analysis based on the census would offer. But this 500 -fold enlargement of cases would have the disadvantage of a cross-sectional research design, ${ }^{14}$ which, however, is suited for estimating the proportion of explained variance.

This study has two implications for further research: Firstly, the estimated values of cohort fertility can be used for future research. Compared to the periodic TFR, they enable a better understanding of the district-specific fertility rate differences. For macro-analysis at the district level, the data enable cohort fertility to be taken into consideration. But they also enable identification of specific regional constellations, in particular the identified high-fertility regions in east Baden-Wurttemberg, southern Franconia and in the north-west of North Rhine-Westphalia. More in-depth and focused case analysis of individual districts is promising for researching their causes. Without a doubt, regional fertility analysis supplements the status of research on fertility.

Secondly, the significant findings about the impact of religions, gender proportions and the urbanisation context cluster bring up new questions with regard to methodology and theory formation. This is especially the case when assessing the shares that composition effects and the district-specific context have in the overall explanation of the CTFR. One challenge is the difficulty to differenciate between variables that can have both individual and structural effects. One example of this is the percentage of Catholics, since the Catholic denomination is an individual characteristic, but the factor aggregates the effect of Catholicism and thus measures an important cultural factor. Overall, the study provides several new insights into the nexus between district-specific contexts and cohort fertility.

14 This would, for example, not clarify the extent to which the urbanisation effect is caused by internal mobility between urban and rural areas or by the fertility behaviour of women who live in large cities for the long term (Boyle et al. 2007; Kulu/Boyle 2009). 


\section{Acknowledgements}

This article has benefitted from valuable comments by Sebastian Klüsener, Stephan Kühntopf, Ralina Panova, Manfred Scharein and Felix zur Nieden as well as by two anonymous reviewers. Further we thank Kai Dreschmitt for literature research and the census team at the Federal Statistical Office, especially Sabrina Estatico, for support with data specific questions.

\section{References}

Andorka, Rudolf 1978: Determinants of Fertility in Advanced Societies. London: Methuen \& Co.

Baizán, Pau 2009: Regional child care availability and fertility decisions in Spain. In: Demographic Research 21,27: 803-842 [doi: 10.4054/DemRes.2009.21.27].

Basten, Stuart; Huinink, Johannes; Klüsener, Sebastian 2011: Spatial Variation of Subnational Fertility Trends in Austria, Germany and Switzerland. In: Comparative Population Studies 36,2-3: 573-614 [doi: 10.4232/10.CPoS-2011-08en].

Bauernschuster, Stefan; Hener, Timo; Rainer, Helmut 2013: Does expanding public child care encourage fertility? County-level evidence from Germany. Ifo Working Paper 158.

BBSR (Bundesinstitut für Bau-, Stadt- und Raumforschung) (Ed.) 2015: Indikatoren und Karten zur Raum- und Stadtentwicklung. INKAR [http://www.inkar.de/, 01.06.2016].

Bechtold, Sabine 2016: The 2011 Census Model in Germany. In: Comparative Population Studies 4: D1-D9 [doi: 10.12765/CPoS-2016-07en].

Bongaarts, John; Feeney, Griffith 1998: On the Quantum and Tempo of Fertility. In: Population and Development Review 24,2: 271-291.

Boyle, Paul J.; Graham, Elspeth; Feng, Zhiqiang 2007: The significance of local clusters of fertility in Scotland. MPIDR Working paper WP 2007-036.

Bujard, Martin 2011: Geburtenrückgang und Familienpolitik. Baden-Baden: Nomos.

Bujard, Martin; Sulak, Harun 2016: Mehr Kinderlose oder weniger Kinderreiche? In: Kölner Zeitschrift für Soziologie und Sozialpsychologie 68,3: 487-514.

Castles, Francis G. 2003: The world turned upside down: Below replacement fertility, changing preferences and family-friendly public policy in 21 OECD countries. In: Journal of European Social Policy 13,3: 209-227 [doi: 10.1177/09589287030133001].

Coale, Ansley J.; Watkins, Susan C. 1986: The Decline of Fertility in Europe. Princeton: University Press.

Courgeau, Danie/ 1989: Family formation and urbanization. In: Population 44,1: 123-146.

Fiori, Francesca; Graham, Elspeth; Feng, Zhiqiang 2014: Geographical variations in fertility and transition to second and third birth in Britain. In: Advances in Life Course Research 21: 149-167 [doi: 10.1016/j.alcr.2013.11.004].

Fotheringham, A. Stewart; Wong, David W.S. 1991: The Modifiable Areal Unit Problem in Multivariate Statistical Analysis. In: Environment and Planning A 23: 1025-1044 [doi: 10.1068/a231025].

Fulda, Barbara 2015: Culture's Influence. Regionally Differing Social Milieus and Variations in Fertility Rates. MPIfG Discussion Paper 15/4. 
Goldstein, Joshua R.; Klüsener, Sebastian 2014: Spatial analysis of the causes of fertility decline in Prussia. In: Population and Development Review 40,3: 497-525 [doi: 10.1111/j.1728-4457.2014.00695.x].

Goldstein, Joshua R.; Kreyenfeld, Michaela 2011: Has East Germany overtaken West Germany? Recent trends in order-specific fertility. In: Population and Development Review 37,3: 453-472 [doi: 10.1111/j.1728-4457.2011.00430.x].

Goldstein, Joshua R.; Kreyenfeld, Michaela 2013: Cohort_DATA_Germany_HFD. Unpublished data sheet.

Grünheid, Evelyn 2015: Regionale Aspekte des demografischen Wandels. Wiesbaden: Bundesinstitut für Bevölkerungsforschung.

Hank, Karsten 2001: Regional fertility differences in Western Germany: An Overview of the Literature and Recent Descriptive Findings. In: International Journal of Population Geography 7,4: 243-257.

Hank, Karsten 2002: Regional Social Contexts and Individual Fertility Decisions: A Multilevel Analysis of First and Second Births in Western Germany. In: European Journal of Population 18: 281-299 [doi: 10.1023/A:1019765026537].

Hank, Karsten 2003: The Differential Influence of Women's Residential District on the Risk of Entering First Marriage and Motherhood in Western Germany. In: Population and Environment 25: 3-21 [doi: 10.1023/A:1025546221461].

Hank, Karsten; Huinink, Johannes 2015: Regional Contexts and Family Formation. In: Hank, Karsten; Kreyenfeld, Michaela (Eds.): Social demography. Kölner Zeitschrift für Soziologie und Sozialpsychologie, Sonderheft 55. Wiesbaden: Springer VS: 41-58.

Hank, Karsten; Kreyenfeld, Michaela; Spieß, C. Katharina 2004: Kinderbetreuung und Fertilität in Deutschland. In: Zeitschrift für Soziologie 33: 228-244.

Huinink, Johannes; Wagner, Michael 1989: Regionale Lebensbedingungen, Migration und Familienbildung. In: KöIner Zeitschrift für Soziologie und Sozialpsychologie 41: 669-689.

Kemper, Franz-Josef 1991: Recent developments in household and family structure and their impact on regional fertility differences. In: Bähr, Jürgen; Gans, Paul (Eds.): The Geographical Approach to fertility. Kiel: 219-228.

Klüsener, Sebastian 2009: An Alternative Framework for Studying the Effects of Family Policies on Fertility in the Absence of Individual-Level Data. MPIDR WP 2009-027.

Klüsener, Sebastian; Goldstein, Joshua R. 2014: A Long-Standing Demographic EastWest Divide in Germany. In: Population, Space, and Place 22,1: 5-22 [doi: 10.1002/ psp.1870].

Knodel, John; van de Walle, Etienne 1986: Lessons from the Past: Policy Implications of Historical Fertility Studies. In: Coale, Ansley J.; Watkins, Susan C. (Eds.): The Decline of Fertility in Europe. Princeton: University Press: 390-419.

Kravdal, Øystein 2002: The impact of individual and aggregate unemployment on fertility in Norway. In: Demographic Research 6,10: 263-294 [doi: 10.4054/DemRes.2002.6.10].

Kreuzmair, Ingrid; Reisch, Marco 2013: ZENSUS 2011. Ablauf der Haushaltegenerierung [https://www.zensus2011.de/SharedDocs/Downloads/DE/Publikationen/Aufsaetze Archiv/2013_04_BW_Ablauf_der_Haushaltegenerierung.html, 01.06.2016].

Kühntopf, Stephan 2015: Kreisumschätzer. Unveröffentlichte Tabelle. Wiesbaden: BiB.

Kulu, Hill 2013: Why Do Fertility Levels Vary between Urban and Rural Areas? In: Regional Studies 47,6: 1-18. 
Kulu, Hill; Milewski, Nadja 2007: Family change and migration in the life course: An introduction. In: Demographic Research 17,19: 567-590 [doi: 10.4054/DemRes.2007.17.19].

Kulu, Hill; Vikat, Andres; Andersson, Gunnar 2007: Settlement size and fertility in the Nordic countries. In: Population Studies 61,3: 265-285 [doi: 10.1080/00324720701571749].

Kulu, Hill; Vikat, Andres 2007: Fertility differences by housing type: The effect of housing conditions or of selective moves? In: Demographic Research 17,26: 775-802 [doi: 10.4054/DemRes.2007.17.26].

Kulu, Hill; Boyle, Paul J. 2009: High Fertility in City Suburbs: Compositional or Contextual Effects? In: European Journal of Population 25,2: 157-174 [doi: 10.1007/s10680 008-9163-9].

Kulu, Hill; Washbrook, Elizabeth 2014: Residential context, migration and fertility in a modern urban society. In: Advances in Life Course Research 21: 168-182 [doi: 10.1016/j.alcr.2014.01.001].

Lesthaeghe, Ron 1995: The Second Demographic Transition in Western Countries: An Interpretation. In: Mason, Karen O.; Jensen, An-Magritt (Eds.): Gender and Family Change in Industrialized Countries. Oxford: Clarendon Press: 17-62.

Luci-Greulich, Angela; Thévenon, Olivier 2013: The impact of family policies on fertility trends in developed countries. In: European Journal of Population 29,4: 387-416 [doi: 10.1007/s10680-013-9295-4].

Lutz, Wolfgang; Testa, Maria R.; Penn, Dustin 2006: Population density is a key factor in declining human fertility. In: Population and Environment 28,2: $69-81$ [doi: 10.1007/ s11111-007-0037-6].

Luy, Marc 2010: Tempo Effects and their Relevance in Demographic Analysis. In: Comparative Population Studies 35,3: 415-446 [doi: 10.4232/10.CPoS-2010-11en].

Michielin, Francesca 2002: Lowest low fertility in an urban context. When migration plays a key role. MPIDR Working paper WP 2002-050.

Mills, Melinda; Blossfeld, Hans-Peter 2005: Globalization, Uncertainty and the Early Life Course: A Theoretical Framework. In: Blossfeld, Hans-Peter et al. (Eds.): Globalization, Uncertainty and Youth in Society. London: Routledge: 1-14.

Openshaw, Stan 1984: The Modifiable Areal Unit Problem. Norwich: Geo Books.

Pötzsch, Olga 2010: Cohort fertility: A Comparison of the Results of the Official Birth Statistics and of the Microcensus Survey 2008. In: Comparative Population Studies 35,1: 185-204 [doi: 10.4232/10.CPoS-2010-05en].

Rindfuss, Ronald R. et al. 2007: Child Care Availability and First-Birth Timing in Norway. In: Demography 44,2: 345-372 [doi: 10.1353/dem.2007.0017].

Rokkan, Stein 1970: Citizens Elections Parties. Approaches to the Comparative Study of the Processes of Development. Oslo: Universitetsforlaget.

Schneider, Norbert F.; Naderi, Robert; Ruppenthal, Silvia 2012: Familie in Deutschland nach dem gesellschaftlichen Umbruch. In: Huinink, Johannes; Kreyenfeld, Michaela; Trappe, Heike (Eds.): Familie und Partnerschaft in Ost- und Westdeutschland: 29-53.

Schoen, Robert 2004: Timing effects and the interpretation of period fertility. In: Demography 41,4: 801-819 [doi: 10.1353/dem.2004.0036].

Sharlin, Allan 1986: Urban-Rural Differences in Fertility in Europe during the Demographic Transition. In: Coale, Ansley J.; Watkins, Susan C. (Eds.): The Decline of Fertility in Europe. Princeton: University Press: 234-260.

Sobotka, Tomáš; Feray, Adigüzel 2002: Religiosity and Spatial Demographic Differences in the Netherlands. SOM Research Report. Groningen: University of Groningen. 
Statistisches Bundesamt 2010: Haushaltebefragung beim Zensus 2011. Wiesbaden.

Statistisches Bundesamt 2012: Bevölkerung und Erwerbstätigkeit. Fachserie 1 Reihe 1.1. Wiesbaden.

Statistisches Bundesamt 2014: Altersspezifische Geburtenziffern der Geburtsjahrgänge 1930 bis 1997 . Wiesbaden.

Statistisches Bundesamt 2015: Die Haushaltegenerierung - mehr als nur die Bildung von Haushalten [https://www.zensus2011.de/DE/Zensus2011/Methode/Methode Haushaltegenerierung_node.html, 01.06.2016].

Trovato, Frank; Grindstaff, Carl F. 1980: Decomposing the Urban-Rural Fertility Differential: Canada, 1971. In: Rural Sociology 45: 448-468.

Wolf, Julius 1912: Der Geburtenrückgang. Die Rationalisierung des Sexuallebens in unserer Zeit. Jena: Gustav Fischer.

Dr. Martin Bujard $(\bowtie)$. Federal Institute for Population Research. Wiesbaden, Germany. E-mail: martin.bujard@bib.bund.de URL: http://www.bib-demografie.de/bujard_cv

Melanie Scheller. Federal Statistical Office. Wiesbaden, Germany. E-mail: melanie.scheller@destatis.de

URL: https://www.destatis.de/EN/Homepage.html 


\section{Appendix}

Fig. A1: Numbered key of the 402 German districts

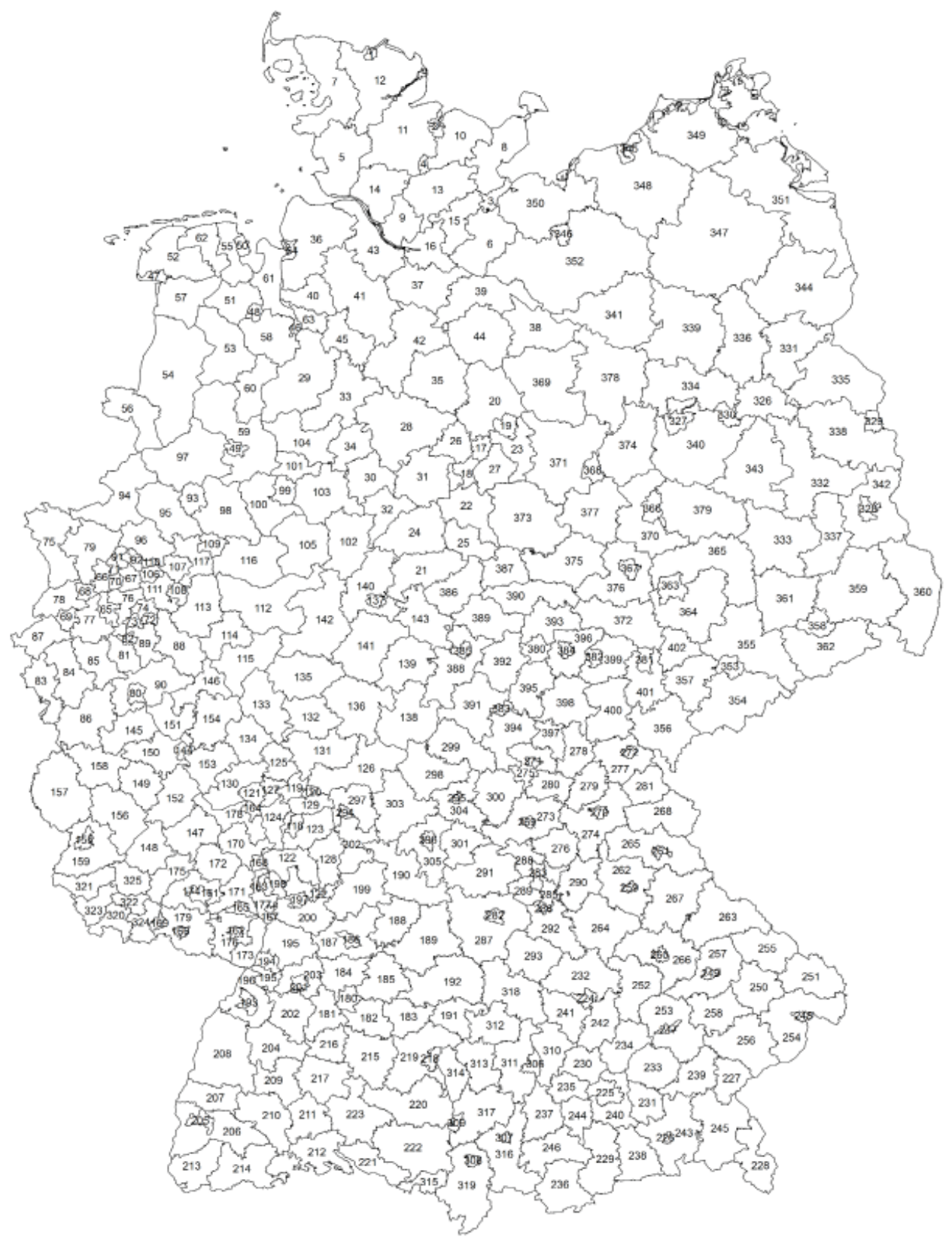

Source: Own graph. Map: () GeoBasis-DE/BKG (2015). 
Tab. A1: Name, numbered key and estimated CTFR for cohorts 1969-72 for the 402 German districts

\begin{tabular}{|c|c|c|c|c|c|c|c|c|}
\hline Key & District & CTFR & Key & District & CTFR & Key & District & CTFR \\
\hline 1 & Flensburg, city & 1.39 & 51 & Ammerland & 1.63 & 101 & Herford & 1.48 \\
\hline 2 & Kiel, regional capital & 1.11 & 52 & Aurich & 1.60 & 102 & Höxter & 1.66 \\
\hline 3 & Lübeck, Hanseatic city & 1.30 & 53 & Cloppenburg & 2.01 & 103 & Lippe & 1.55 \\
\hline 4 & Neumünster, city & 1.31 & 54 & Emsland & 1.82 & 104 & Minden-Lübbecke & 1.66 \\
\hline 5 & Dithmarschen & 1.50 & 55 & Friesland & 1.60 & 105 & Paderborn & 1.67 \\
\hline 6 & Duchy of Lauenburg & 1.53 & 56 & County of Bentheim & 1.67 & 106 & Bochum, city & 1.36 \\
\hline 7 & North Frisia & 1.53 & 57 & Leer & 1.67 & 107 & Dortmund, city & 1.42 \\
\hline 8 & Ostholstein & 1.43 & 58 & Oldenburg & 1.47 & 108 & Hagen, city & 1.59 \\
\hline 9 & Pinneberg & 1.42 & 59 & Osnabrück & 1.72 & 109 & Hamm, city & 1.63 \\
\hline 10 & Plön & 1.48 & 60 & Vechta & 1.86 & 110 & Herne, city & 1.58 \\
\hline 11 & Rendsburg-Eckernförde & 1.53 & 61 & Wesermarsch & 1.61 & 111 & Ennepe-Ruhr-Kreis & 1.39 \\
\hline 12 & Schleswig-Flensburg & 1.57 & 62 & Wittmund & 1.55 & 112 & Hochsauerlandkreis & 1.70 \\
\hline 13 & Segeberg & 1.43 & 63 & Bremen, city & 1.28 & 113 & Märkischer Kreis & 1.45 \\
\hline 14 & Steinburg & 1.34 & 64 & Bremerhaven, city & 1.43 & 114 & Olpe & 1.76 \\
\hline 15 & Stormarn & 1.43 & 65 & Düsseldorf, city & 1.18 & 115 & Siegen-Wittgenstein & 1.61 \\
\hline 16 & Hamburg & 1.27 & 66 & Duisburg, city & 1.56 & 116 & Soest & 1.61 \\
\hline 17 & Braunschweig, city & 1.37 & 67 & Essen, city & 1.29 & 117 & Unna & 1.57 \\
\hline 18 & Salzgitter, city & 1.50 & 68 & Krefeld, city & 1.57 & 118 & Darmstadt, city & 1.44 \\
\hline 19 & Wolfsburg, city & 1.53 & 69 & Mönchengladbach, city & 1.49 & 119 & Frankfurt/Main, city & 1.20 \\
\hline 20 & Gifhorn & 1.63 & 70 & Mülheim/Ruhr, city & 1.37 & 120 & Offenbach/Main, city & 1.41 \\
\hline 21 & Göttingen & 1.49 & 71 & Oberhausen, city & 1.43 & 121 & Wiesbaden, city & 1.31 \\
\hline 22 & Goslar & 1.47 & 72 & Remscheid, city & 1.47 & 122 & Bergstraße & 1.42 \\
\hline 23 & Helmstedt & 1.51 & 73 & Solingen, city & 1.52 & 123 & Darmstadt-Dieburg & 1.42 \\
\hline 24 & Northeim & 1.67 & 74 & Wuppertal, city & 1.61 & 124 & Groß-Gerau & 1.48 \\
\hline 25 & Osterode am Harz & 1.55 & 75 & Kleve & 1.63 & 125 & Hochtaunuskreis & 1.49 \\
\hline 26 & Peine & 1.60 & 76 & Mettmann & 1.39 & 126 & Main-Kinzig-Kreis & 1.48 \\
\hline 27 & Wolfenbüttel & 1.47 & 77 & Rhein-Kreis Neuss & 1.49 & 127 & Main-Taunus-Kreis & 1.47 \\
\hline 28 & Hanover region & 1.40 & 78 & Viersen & 1.51 & 128 & Odenwaldkreis & 1.60 \\
\hline 29 & Diepholz & 1.59 & 79 & Wesel & 1.54 & 129 & Offenbach & 1.38 \\
\hline 30 & Hameln-Pyrmont & 1.45 & 80 & Bonn, city & 1.34 & 130 & Rheingau-Taunus-Kreis & 1.42 \\
\hline 31 & Hildesheim & 1.51 & 81 & Cologne city & 1.19 & 131 & Wetteraukreis & 1.46 \\
\hline 32 & Holzminden & 1.56 & 82 & Leverkusen, city & 1.36 & 132 & Gießen & 1.45 \\
\hline 33 & Nienburg/Weser & 1.53 & 83 & Aachen & 1.46 & 133 & Lahn-Dill-Kreis & 1.61 \\
\hline 34 & Schaumburg & 1.61 & 84 & Düren & 1.56 & 134 & Limburg-Weilburg & 1.61 \\
\hline 35 & Celle & 1.65 & 85 & Rhein-Erft-Kreis & 1.56 & 135 & Marburg-Biedenkopf & 1.55 \\
\hline 36 & Cuxhaven & 1.51 & 86 & Euskirchen & 1.50 & 136 & Vogelsbergkreis & 1.65 \\
\hline 37 & Harburg & 1.37 & 87 & Heinsberg & 1.57 & 137 & Kassel, city & 1.48 \\
\hline 38 & Lüchow-Dannenberg & 1.24 & 88 & Oberbergischer Kreis & 1.65 & 138 & Fulda & 1.64 \\
\hline 39 & Lüneburg & 1.48 & 89 & Rheinisch-Bergisch. Kreis & 1.55 & 139 & Hersfeld-Rotenburg & 1.51 \\
\hline 40 & Osterholz & 1.46 & 90 & Rhein-Sieg-Kreis & 1.55 & 140 & Kassel & 1.43 \\
\hline 41 & Rotenburg/Wümme & 1.69 & 91 & Bottrop, city & 1.37 & 141 & Schwalm-Eder-Kreis & 1.53 \\
\hline 42 & Soltau-Fallingbostel & 1.53 & 92 & Gelsenkirchen, city & 1.59 & 142 & Waldeck-Frankenberg & 1.46 \\
\hline 43 & Stade & 1.62 & 93 & Münster, city & 1.44 & 143 & Werra-Meißner-Kreis & 1.64 \\
\hline 44 & Uelzen & 1.41 & 94 & Borken & 1.78 & 144 & Koblenz, city & 1.35 \\
\hline 45 & Verden & 1.54 & 95 & Coesfeld & 1.65 & 145 & Ahrweiler & 1.54 \\
\hline 46 & Delmenhorst, city & 1.64 & 96 & Recklinghausen & 1.46 & 146 & Altenkirchen (Westerwald) & 1.57 \\
\hline 47 & Emden, city & 1.68 & 97 & Steinfurt & 1.76 & 147 & Bad Kreuznach & 1.41 \\
\hline 48 & Oldenburg, city & 1.37 & 98 & Warendorf & 1.65 & 148 & Birkenfeld & 1.44 \\
\hline 49 & Osnabrück, city & 1.21 & 99 & Bielefeld, city & 1.40 & 149 & Cochem-Zell & 1.60 \\
\hline 50 & Wilhelmshaven, city & 1.33 & 100 & Gütersloh & 1.62 & 150 & Mayen-Koblenz & 1.52 \\
\hline
\end{tabular}


Tab. A1: Continuation

\begin{tabular}{|c|c|c|c|c|c|c|c|c|}
\hline Key & District & CTFR & Key & District & CTFR & Key & District & CTFR \\
\hline 151 & Neuwied & 1.57 & 201 & Pforzheim, city & 1.75 & 251 & Freyung-Grafenau & 1.61 \\
\hline 152 & Rhein-Hunsrück-Kreis & 1.59 & 202 & Calw & 1.71 & 252 & Kelheim & 1.71 \\
\hline 153 & Rhein-Lahn-Kreis & 1.48 & 203 & Enzkreis & 1.62 & 253 & Landshut & 1.64 \\
\hline 154 & Westerwaldkreis & 1.65 & 204 & Freudenstadt & 1.86 & 254 & Passau & 1.65 \\
\hline 155 & Trier, city & 1.29 & 205 & Freiburg im Breisgau, city & 1.32 & 255 & Regen & 1.51 \\
\hline 156 & Bernkastel-Wittlich & 1.66 & 206 & Breisgau-Hochschwarzwald & 1.63 & 256 & Rottal-Inn & 1.84 \\
\hline 157 & Bitburg-Prüm & 1.65 & 207 & Emmendingen & 1.62 & 257 & Straubing-Bogen & 1.84 \\
\hline 158 & Daun & 1.83 & 208 & Ortenaukreis & 1.62 & 258 & Dingolfing-Landau & 1.66 \\
\hline 159 & Trier-Saarburg & 1.56 & 209 & Rottweil & 1.70 & 259 & Amberg, city & 1.31 \\
\hline 160 & Frankenthal (Palatinate), city & 1.44 & 210 & Schwarzwald-Baar-Kreis & 1.63 & 260 & Regensburg, city & 1.26 \\
\hline 161 & Kaiserslautern, city & 1.26 & 211 & Tuttlingen & 1.77 & 261 & Weiden i.d.OPf., city & 1.16 \\
\hline 162 & Landau in der Pfalz (Palatinate), city & 1.46 & 212 & Konstanz & 1.47 & 262 & Amberg-Sulzbach & 1.61 \\
\hline 163 & Ludwigshafen/Rhein & 1.41 & 213 & Lörrach & 1.60 & 263 & Cham & 1.64 \\
\hline 164 & Mainz, city & 1.42 & 214 & Waldshut & 1.56 & 264 & Neumarkt i.d.OPf. & 1.74 \\
\hline 165 & Neustadt Weinstraße, city & 1.54 & 215 & Reutlingen & 1.60 & 265 & Neustadt a.d.Waldnaab & 1.73 \\
\hline 166 & Pirmasens, dity & 1.27 & 216 & Tübingen & 1.52 & 266 & Regensburg & 1.54 \\
\hline 167 & Speyer, city & 1.60 & 217 & Zollernalbkreis & 1.67 & 267 & Schwandorf & 1.52 \\
\hline 168 & Worms, city & 1.35 & 218 & Ulm, university town & 1.42 & 268 & Tirschenreuth & 1.78 \\
\hline 169 & Zweibrücken, city & 1.40 & 219 & Alb-Donau-Kreis & 1.76 & 269 & Bamberg, city & 1.21 \\
\hline 170 & Alzey-Worms & 1.58 & 220 & Biberach & 1.81 & 270 & Bayreuth, city & 1.44 \\
\hline 171 & Bad Dürkheim & 1.54 & 221 & Lake Constance District & 1.60 & 271 & Coburg, city & 1.51 \\
\hline 172 & Donnersbergkreis & 1.56 & 222 & Ravensburg & 1.78 & 272 & Hof, city & 1.38 \\
\hline 173 & Germersheim & 1.53 & 223 & Sigmaringen & 1.66 & 273 & Bamberg & 1.61 \\
\hline 174 & Kaiserslautern & 1.55 & 224 & Ingolstadt, Stadt & 1.41 & 274 & Bayreuth & 1.59 \\
\hline 175 & Kusel & 1.44 & 225 & Munich, regional capital & 1.18 & 275 & Coburg & 1.63 \\
\hline 176 & Südliche Weinstraße & 1.51 & 226 & Rosenheim, city & 1.39 & 276 & Forchheim & 1.68 \\
\hline 177 & Rhein-Pfalz-Kreis & 1.37 & 227 & Altötting & 1.63 & 277 & Hof & 1.45 \\
\hline 178 & Mainz-Bingen & 1.39 & 228 & Berchtesgadener Land & 1.51 & 278 & Kronach & 1.48 \\
\hline 179 & Südwestpfalz & 1.52 & 229 & Bad Tölz-Wolfratshausen & 1.64 & 279 & Kulmbach & 1.47 \\
\hline 180 & Stuttgart, regional capital & 1.29 & 230 & Dachau & 1.53 & 280 & Lichtenfels & 1.78 \\
\hline 181 & Böblingen & 1.52 & 231 & Ebersberg & 1.61 & 281 & Wunsiedel/Fichtel Mountains & 1.23 \\
\hline 182 & Esslingen & 1.49 & 232 & Eichstätt & 1.86 & 282 & Ansbach, city & 1.43 \\
\hline 183 & Göppingen & 1.61 & 233 & Erding & 1.59 & 283 & Erlangen, city & 1.32 \\
\hline 184 & Ludwigsburg & 1.55 & 234 & Freising & 1.55 & 284 & Fürth, city & 1.31 \\
\hline 185 & Rems-Murr-Kreis & 1.55 & 235 & Fürstenfeldbruck & 1.44 & 285 & Nuremberg, city & 1.26 \\
\hline 186 & Heilbronn, city & 1.49 & 236 & Garmisch-Partenkirchen & 1.53 & 286 & Schwabach, city & 1.34 \\
\hline 187 & Heilbronn & 1.70 & 237 & Landsberg/Lech & 1.81 & 287 & Ansbach & 1.63 \\
\hline 188 & Hohenlohekreis & 1.78 & 238 & Miesbach & 1.57 & 288 & Erlangen-Höchstadt & 1.49 \\
\hline 189 & Schwäbisch Hall & 1.76 & 239 & Mühldorf/Inn & 1.87 & 289 & Fürth & 1.40 \\
\hline 190 & Main-Tauber-Kreis & 1.75 & 240 & Munich & 1.51 & 290 & Nürnberger Land & 1.44 \\
\hline 191 & Heidenheim & 1.78 & 241 & Neuburg-Schrobenhausen & 1.60 & 291 & Neustadt a.d.Aisch-Bad W. & 1.57 \\
\hline 192 & Ostalbkreis & 1.76 & 242 & Pfaffenhofen a.d.IIm & 1.62 & 292 & Roth & 1.66 \\
\hline 193 & Baden-Baden, city & 1.22 & 243 & Rosenheim & 1.69 & 293 & Weißenburg-Gunzenhausen & 1.73 \\
\hline 194 & Karlsruhe, city & 1.26 & 244 & Starnberg & 1.56 & 294 & Aschaffenburg, city & 1.50 \\
\hline 195 & Karlsruhe & 1.52 & 245 & Traunstein & 1.67 & 295 & Schweinfurt, city & 1.77 \\
\hline 196 & Rastatt & 1.53 & 246 & Weilheim-Schongau & 1.71 & 296 & Würzburg, city & 1.16 \\
\hline 197 & Heidelberg, city & 1.36 & 247 & Landshut, city & 1.27 & 297 & Aschaffenburg & 1.64 \\
\hline 198 & Mannheim, city & 1.34 & 248 & Passau, city & 1.05 & 298 & Bad Kissingen & 1.63 \\
\hline 199 & Neckar-Odenwald-Kreis & 1.84 & 249 & Straubing, city & 1.60 & 299 & Rhön-Grabfeld & 1.64 \\
\hline 200 & Rhein-Neckar-Kreis & 1.49 & 250 & Deggendorf & 1.47 & 300 & Haßberge & 1.64 \\
\hline
\end{tabular}


Tab. A1: Continuation

\begin{tabular}{|c|c|c|c|c|c|c|c|c|}
\hline Key & District & CTFR & Key & District & CTFR & Key & District & CTFR \\
\hline 301 & Kitzingen & 1.77 & 351 & Vorpommern-Greifswald & 1.45 & 401 & Greiz & 1.67 \\
\hline 302 & Miltenberg & 1.60 & 352 & Ludwigslust-Parchim & 1.51 & 402 & Altenburger Land & 1.46 \\
\hline 303 & Main-Spessart & 1.57 & 353 & Chemnitz & 1.65 & & & \\
\hline 304 & Schweinfurt & 1.66 & 354 & Erzgebirgskreis & 1.71 & & & \\
\hline 305 & Würzburg & 1.51 & 355 & Central Saxony & 1.62 & & & \\
\hline 306 & Augsburg, city & 1.28 & 356 & Vogtlandkreis & 1.56 & & & \\
\hline 307 & Kaufbeuren, city & 1.54 & 357 & Zwickau & 1.56 & & & \\
\hline 308 & Kempten, city & 1.45 & 358 & Dresden & 1.52 & & & \\
\hline 309 & Memmingen, city & 1.50 & 359 & Bautzen & 1.61 & & & \\
\hline 310 & Aichach-Friedberg & 1.59 & 360 & Görlitz & 1.73 & & & \\
\hline 311 & Augsburg & 1.67 & 361 & Meißen & 1.66 & & & \\
\hline 312 & Dillingen/Donau & 1.62 & 362 & Saxon Switzerland-East Ore Mountains & 1.65 & & & \\
\hline 313 & Günzburg & 1.88 & 363 & Leipzig, city & 1.34 & & & \\
\hline 314 & Neu-Ulm & 1.74 & 364 & Leipzig & 1.51 & & & \\
\hline 315 & Lindau (Lake Constance) & 1.50 & 365 & North Saxony & 1.62 & & & \\
\hline 316 & Ostallgäu & 1.76 & 366 & Dessau-Roßlau & 1.37 & & & \\
\hline 317 & Unterallgäu & 1.80 & 367 & Halle/Saale & 1.40 & & & \\
\hline 318 & Donau-Ries & 1.65 & 368 & Magdeburg & 1.45 & & & \\
\hline 319 & Oberallgäu & 1.57 & 369 & Altmarkkreis Salzwedel & 1.62 & & & \\
\hline 320 & Stadtverband Saarbrücken & 1.34 & 370 & Anhalt-Bitterfeld & 1.47 & & & \\
\hline 321 & Merzig-Wadern & 1.57 & 371 & Börde & 1.53 & & & \\
\hline 322 & Neunkirchen & 1.46 & 372 & Burgenlandkreis & 1.51 & & & \\
\hline 323 & Saarlouis & 1.38 & 373 & Harz & 1.47 & & & \\
\hline 324 & Saarpfalz-Kreis & 1.39 & 374 & Jerichower Land & 1.38 & & & \\
\hline 325 & St. Wendel & 1.39 & 375 & Mansfeld-Südharz & 1.55 & & & \\
\hline 326 & Berlin & 1.37 & 376 & Saalekreis & 1.48 & & & \\
\hline 327 & Brandenburg/Havel & 1.24 & 377 & Salzlandkreis & 1.46 & & & \\
\hline 328 & Cottbus, city & 1.44 & 378 & Stendal & 1.58 & & & \\
\hline 329 & Frankfurt/Oder, city & 1.34 & 379 & Wittenberg & 1.52 & & & \\
\hline 330 & Potsdam, city & 1.35 & 380 & Erfurt, city & 1.48 & & & \\
\hline 331 & Barnim & 1.47 & 381 & Gera, city & 1.11 & & & \\
\hline 332 & Dahme-Spreewald & 1.50 & 382 & Jena, city & 1.47 & & & \\
\hline 333 & Elbe-Elster & 1.68 & 383 & Suhl, city & 1.39 & & & \\
\hline 334 & Havelland & 1.59 & 384 & Weimar, city & 1.41 & & & \\
\hline 335 & Märkisch-Oderland & 1.49 & 385 & Eisenach, city & 1.33 & & & \\
\hline 336 & Oberhavel & 1.48 & 386 & Eichsfeld & 1.66 & & & \\
\hline 337 & Oberspreewald-Lausitz & 1.64 & 387 & Nordhausen & 1.32 & & & \\
\hline 338 & Oder-Spree & 1.47 & 388 & Wartburgkreis & 1.68 & & & \\
\hline 339 & Ostprignitz-Ruppin & 1.53 & 389 & Unstrut-Hainich-Kreis & 1.60 & & & \\
\hline 340 & Potsdam-Mittelmark & 1.62 & 390 & Kyffhäuserkreis & 1.52 & & & \\
\hline 341 & Prignitz & 1.63 & 391 & Schmalkalden-Meiningen & 1.58 & & & \\
\hline 342 & Spree-Neiße & 1.52 & 392 & Gotha & 1.53 & & & \\
\hline 343 & Teltow-Fläming & 1.53 & 393 & Sömmerda & 1.63 & & & \\
\hline 344 & Uckermark & 1.42 & 394 & Hildburghausen & 1.54 & & & \\
\hline 345 & Rostock & 1.38 & 395 & IIm-Kreis & 1.44 & & & \\
\hline 346 & Schwerin & 1.41 & 396 & Weimarer Land & 1.44 & & & \\
\hline 347 & Mecklenburgische Seenplatte & 1.53 & 397 & Sonneberg & 1.33 & & & \\
\hline 348 & rural district of Rostock & 1.58 & 398 & Saalfeld-Rudolstadt & 1.43 & & & \\
\hline 349 & Vorpommern-Rügen & 1.53 & 399 & Saale-Holzland-Kreis & 1.48 & & & \\
\hline 350 & Northwestern Mecklenburg & 1.71 & 400 & Saale-Orla-Kreis & 1.49 & & & \\
\hline
\end{tabular}

Note: An Excel file with the 5-digit district code, the district names, the Länder and the CTFR-estimations is provided at:

http://www.comparativepopulationstudies.de/index.php/CPoS/article/view/270/241

Source: Own calculations based on the 2011 census. 


\section{Comparative Population Studies}

wWW.comparativepopulationstudies.de

ISSN: 1869-8980 (Print) - 1869-8999 (Internet)

\section{Published by}

Prof. Dr. Norbert F. Schneider

Federal Institute for Population Research D-65180 Wiesbaden / Germany

\section{(cc) BY-SA}

2017

\section{Managing Editor}

Frank Swiaczny

\section{Assistant Managing Editor}

Katrin Schiefer

\section{Copy Editor}

(Selected Articles in German)

Dr. Evelyn Grünheid

\section{Layout}

Beatriz Feiler-Fuchs

E-mail: cpos@bib.bund.de

\section{Scientific Advisory Board}

Paul Gans (Mannheim)

Karsten Hank (Cologne)

Johannes Huinink (Bremen)

Michaela Kreyenfeld (Rostock)

Marc Luy (Vienna)

Notburga Ott (Bochum)

Peter Preisendörfer (Mainz)

Nikola Sander (Groningen)

Zsolt Spéder (Budapest)

\section{Board of Reviewers}

Martin Abraham (Erlangen)

Laura Bernardi (Lausanne)

Hansjörg Bucher (Bonn)

Claudia Diehl (Konstanz)

Andreas Diekmann (Zurich)

Gabriele Doblhammer-Reiter (Rostock)

Jürgen Dorbritz (Wiesbaden)

Anette Eva Fasang (Berlin)

E.-Jürgen Flöthmann (Bielefeld)

Alexia Fürnkranz-Prskawetz (Vienna)

Beat Fux (Salzburg)

Joshua Goldstein (Berkeley)

Sonja Haug (Regensburg)

Hill Kulu (Liverpool)

Aart C. Liefbroer (The Hague)

Kurt Lüscher (Konstanz)

Emma Lundholm (Umeå)

Nadja Milewski (Rostock)

Dimiter Philipov (Vienna)

Roland Rau (Rostock)

Tomáš Sobotka (Vienna)

Jeroen Spijker (Barcelona)

Olivier Thévenon (Paris)

Helga de Valk (Brussels)

Heike Trappe (Rostock)

Michael Wagner (Cologne) 